\title{
What should we advise MAFLD patients to eat and drink?
}

\author{
Mariana Verdelho Machado ${ }^{1,2}$ \\ ${ }^{1}$ Serviço de Gastrenterologia, Hospital de Vila Franca de Xira, Lisboa 1649-035, Portugal. \\ ${ }^{2}$ Faculdade de Medicina, Universidade de Lisboa, Lisboa 1649-035, Portugal.
}

Correspondence to: Mariana Verdelho Machado, MD, PhD, Faculdade de Medicina, Universidade de Lisboa, Avenida Professor Egas Moniz, Lisbon 1649-035, Portugal. E-mail: mverdelhomachado@gmail.com

How to cite this article: Machado MV. What should we advise MAFLD patients to eat and drink? Metab Target Organ Damage 2021;1:9. https://dx.doi.org/10.20517/mtod.2021.11

Received: 13 Sep 2021 First Decision: 13 Oct 2021 Revised: 16 Oct 2021 Accepted: 21 Oct 2021 Published: 28 Oct 2021

Academic Editor: Amedeo Lonardo Copy Editor: Xi-Jun Chen Production Editor: Xi-Jun Chen

\begin{abstract}
In a time of food abundance and waste, and when sedentarism is the norm, metabolic-associated fatty liver disease (MAFLD) has become a major health threat in the Western world. While research is committed to finding a pharmacological treatment for MAFLD, it is time to go back to the basis and address the behavioral pathogenesis of MAFLD. All patients with MAFLD, irrespective of body weight, should be submitted to thorough dietary counseling. Diet is a learned behavior and should be addressed holistically and in a personalized fashion. The benefits of a suitable diet surpass an improvement of liver disease, having the potential to improve cardiovascularand cancer-related mortality, in patients with MAFLD. This review summarizes the current state of the art of diet on MAFLD, presenting straightforward recommendations for everyday practice.
\end{abstract}

Keywords: MAFLD, diet, recommendations

\section{INTRODUCTION}

Throughout human evolution, dietary changes evolved at a rhythm that was not caught up by adaptations in human genome $e^{[1]}$. Dramatic changes in diet occurred in the past two centuries, after the industrial revolution allowed the introduction of prepackaged processed foods, hydrogenated vegetable oils and refined grains ${ }^{[1]}$. Indeed, humans are not adapted to the "western diet", which is hypercaloric, with surplus 
fat and refined sugars, and deficient in vegetables and fibers. This disruptive shift in diet couples with the growing threat of sedentarism, creating the perfect conditions that have led to obesity being the pandemic of the 21 st century.

The metabolic syndrome (MS) and metabolic-associated fatty liver disease (MAFLD) are manifestations of energy surplus, adiposopathy, and obesity. The prevalence of MAFLD increased more than $50 \%$ in the last 35 years, and it is already the number one cause of liver disease worldwide, afflicting one fourth of the overall population ${ }^{[2]}$. Furthermore, MAFLD is the most rapidly increasing etiology for end-stage liver disease $^{[3]}$, having recently reached the podium as the leading cause of chronic liver diseases in women on waitlist for liver transplantation and the second leading cause overall ${ }^{[4]}$. MAFLD is also associated with cardiovascular and all-cause mortality ${ }^{[5]}$.

Recently, a panel of international experts defined as diagnostic criteria for MAFLD the presence of hepatic steatosis in overweight/obese or with type 2 diabetes mellitus (T2DM). In lean non-diabetic patients, besides liver steatosis, the diagnosis of MAFLD requires the presence of at least two metabolic disturbances, such as increased waist circumference, high blood pressure, dyslipidemia, insulin resistance (IR) and prediabetes, or high plasma C-reactive protein ${ }^{[6]}$.

Despite intense research on the quest to find pharmacological treatment for MAFLD, currently no drug has yet been approved for $\mathrm{it}^{[7]}$. We do know, however, that weight loss is effective and can lead to reversal of the disease, with weight loss above $10 \%$ of body weight resulting in steatosis improvement in virtually all patients and fibrosis improvement in four out of five patients ${ }^{[8]}$.

The famous quote from the 19th century by the German philosopher Ludwig Feuerbach "we are what we eat" ${ }^{p[9]}$ is echoing in the field of MAFLD. Indeed, awareness of the effects of our diet on the development and progression of MAFLD is increasing, and a dietary intervention must have a central position in the management of these patients.

This review critically summarizes the associations between diet and MAFLD, as well as the dietary recommendations clinicians should implement on their daily practice.

\section{QUANTITY VS. QUALITY OF THE DIET AS A DRIVER FOR MAFLD}

The first important question is whether diet composition is relevant to the development of MAFLD, or if, on the contrary, it all comes down to a mathematical equation of calories consumption. Table 1 summarizes the nine top epidemiological/observational studies regarding dietary behaviors of patients with MAFLD $^{[10-18]}$, and only two showed an increase in daily energy intake $\mathrm{e}^{[14,15]}$, even in the studies in which patients with MAFLD had clearly a higher body mass index as compared to controls. On the other hand, epidemiological studies presented very heterogeneous differences in the composition of diet in patients with MAFLD as compared to controls, the most consistent one being an increase in proteins intake ${ }^{[1,12,14-18]}$.

The evidence of an association between excessive caloric intake and the development of MAFLD is stronger in interventional studies. Small short-term overfeeding studies on healthy subjects, in which excessive calories were presented either as fat ${ }^{[19]}$ or carbohydrates ${ }^{[20]}$, both were associated with increased body weight and liver fat ${ }^{[21]}$. In the reverse way, overweight or obese subjects submitted to hypocaloric diets restricting carbohydrates or fat presented similar reductions on body weight, liver fat content, and liver enzymes ${ }^{[22,23]}$. The effect of carbohydrates restriction may be faster than with fat restriction, with more pronounced effects after acute restriction $(48 \mathrm{~h}$ ), but similar after chronic restriction (from 11 weeks up to 2 years), when 
Table 1. Summary of the main epidemiological studies evaluating an association between diet and MAFLD

\begin{tabular}{|c|c|c|c|c|c|c|c|c|}
\hline \multirow[b]{2}{*}{ Ref. } & \multirow[b]{2}{*}{ Country } & \multirow[b]{2}{*}{ Study design } & \multirow[b]{2}{*}{$n$} & \multicolumn{5}{|c|}{ Differences in MAFLD vs. control group } \\
\hline & & & & $\begin{array}{l}\mathrm{BMI} \\
\left(\mathrm{kg} / \mathrm{m}^{2}\right)\end{array}$ & Physical activity & $\begin{array}{l}\text { E intake } \\
\text { (kcal/day) }\end{array}$ & Alcohol intake & Macronutrients composition \\
\hline $\begin{array}{l}\text { Musso et al. }{ }^{[10]} \\
2003\end{array}$ & Italy & $\begin{array}{l}\text { Case-control } \\
\text { NASH by liver } \\
\text { biopsy }\end{array}$ & $\begin{array}{l}25 \mathrm{NASH} \\
25 \text { controls }\end{array}$ & $=26$ vs. 25 & - & $=2638$ vs. 2570 & $\begin{array}{l}=13.3 \mathrm{~g} / \text { day vs. } \\
13.5 \mathrm{~g} / \text { day }\end{array}$ & $\begin{array}{l}\text { \% kcal: } \\
=\text { Fat }(35 \text { vs. } 32) ;[\uparrow \text { SFA }(14 \text { vs. } 10),=\text { MUFA }(18 \text { vs. } 17), \downarrow \\
\text { PUFA ( } 3 \text { vs. } 5), \uparrow \text { cholesterol }(506 \text { mg vs. } 405 \text { mg) }] \\
=\text { Carbohydrates ( } 45 \text { vs. } 49) ; \downarrow \text { fiber (13 vs. } 23) \\
\uparrow \text { Proteins ( } 20 \text { vs. } 17)\end{array}$ \\
\hline $\begin{array}{l}\text { Cortez-Pinto et al. }{ }^{[11]} \\
2006\end{array}$ & Portugal & $\begin{array}{l}\text { Case-control } \\
\text { NASH by liver } \\
\text { biopsy }\end{array}$ & $\begin{array}{l}45 \mathrm{NASH} \\
856 \text { controls }\end{array}$ & $\uparrow 31$ vs. 27 & - & $=2253$ vs. 2218 & - & $\begin{array}{l}\text { Intake in g: } \\
\uparrow \text { Fat }(80 \text { vs. } 73) ;[=\text { SFA }(23 \text { vs. } 23), \uparrow \text { MUFA }(38 \text { vs. } 32) \text {, = } \\
\text { PUFA (12 vs. } 12),=\text { cholesterol }(307 \mathrm{mg} \text { vs. } 330 \mathrm{mg})] \\
\downarrow \text { Carbohydrates }(244 \text { vs. } 261) ;=\text { fiber }(23 \text { vs. } 23) \\
\downarrow \text { Proteins }(100 \text { vs. } 105)\end{array}$ \\
\hline $\begin{array}{l}\text { Zelber-Sagi et al. }{ }^{[12]} \\
2007\end{array}$ & Israel & $\begin{array}{l}\text { Cohort } \\
\text { MAFLD by } \\
\text { ultrasound }\end{array}$ & $\begin{array}{l}349(31 \% \\
\text { MAFLD) }\end{array}$ & $\uparrow 30$ vs. 26 & - & $=2493$ vs. 2382 & - & $\begin{array}{l}\% \text { kcal: } \\
=\text { Fat }(37 \text { vs. } 38) \\
=\text { Carbohydrates }(47 \text { vs. } 47) \\
=\text { Proteins }(18 \text { vs. } 17), \text { but } \uparrow \text { in men }(18 \text { vs. } 17)\end{array}$ \\
\hline Jia et al. ${ }^{[13]} 2015$ & China & $\begin{array}{l}\text { Cohort } \\
\text { MAFLD by } \\
\text { ultrasound }\end{array}$ & $\begin{array}{l}4206(32 \% \\
\text { MAFLD) }\end{array}$ & $\uparrow 27$ vs. 24 & $\begin{array}{l}=12 \mathrm{MET} / \text { week vs. } \\
12 \mathrm{MET} / \text { week }\end{array}$ & $=2218$ vs. 2165 & $\begin{array}{l}\downarrow \text { Daily intake: } 4.3 \% \\
\text { vs. } 8.6 \%\end{array}$ & $\begin{array}{l}\uparrow \text { Carbohydrates intake in women: highest quartile of } \\
\text { intake/sweet pattern score, OR } 2.19 \text { for MAFLD }\end{array}$ \\
\hline $\begin{array}{l}\text { Wehmeyer et al. }{ }^{[14]} \\
2016\end{array}$ & Germany & $\begin{array}{l}\text { Case-control } \\
\text { MAFLD by } \\
\text { ultrasound }\end{array}$ & $\begin{array}{l}55 \text { MAFLD } \\
88 \text { controls }\end{array}$ & $\uparrow 30$ vs. 24 & - & $\uparrow 2739$ vs. 2173 & - & $\begin{array}{l}\text { g/1000 kcal: } \\
=\text { Fat }(43 \text { vs. } 45) ;[=\text { SFA }(18 \text { vs. } 18),=\text { MUFA }(16 \text { vs. } 18),= \\
\text { PUFA ( } \text { vs. } 8)] \\
=\text { Carbohydrates }(104 \text { vs. } 102) ; \downarrow \text { fiber }(9 \text { vs. } 10) \\
\uparrow \text { Proteins }(36 \text { vs. } 35)\end{array}$ \\
\hline Cheng et al..$^{[1]} 2016$ & China & $\begin{array}{l}\text { Case-control } \\
\text { MAFLD by }{ }^{1} H \text {-MRS }\end{array}$ & $\begin{array}{l}19 \text { MAFLD } \\
17 \text { controls }\end{array}$ & $\uparrow 36$ vs. 27 & $\begin{array}{l}=>120 \mathrm{~min} / \text { week: } \\
23 \% \text { vs. } 21 \%\end{array}$ & $\uparrow 2901$ vs. 2423 & - & $\begin{array}{l}\text { Intake in g: } \\
\uparrow \text { Fat }(87 \text { vs. } 60) ;[\uparrow \text { SFA } 8 \text { vs. } 6),=\text { MUFA (11 vs. } 9), \uparrow \text { PUFA } \\
(16 \text { vs. } 11)] \\
\downarrow \text { Carbohydrates }(434 \text { vs. } 391) ;=\text { fiber }(21 \text { vs. } 20) \\
\uparrow \text { Proteins }(97 \text { vs. } 80)\end{array}$ \\
\hline $\begin{array}{l}\text { Rietman et al. }{ }^{[16]} \\
2017\end{array}$ & Netherlands & $\begin{array}{l}\text { Cohort } \\
\text { MAFLD by FLI }\end{array}$ & $\begin{array}{l}1128(21 \% \\
\text { MAFLD) }\end{array}$ & १ 31 vs. 26 & $\begin{array}{l}\downarrow>30 \text { min, moderate: } 2 \\
\text { days vs. } 3 \text { days }\end{array}$ & $=1985$ vs. 2048 & $\begin{array}{l}\uparrow 9.8 \mathrm{~g} / \text { day vs. } 6.8 \\
\mathrm{~g} / \text { day }\end{array}$ & $\begin{array}{l}\% \text { kcal: } \\
=\text { Fat }(37 \text { vs. } 36) ;[=\text { SFA }(12 \text { vs. 12), = MUFA (13 vs. 13), = } \\
\text { PUFA ( } 8 \text { vs. } 9)] \\
\downarrow \text { Carbohydrates ( } 42 \text { vs. } 44) ; \downarrow \text { Fiber ( } 4 \text { vs. } 5) \\
\text { Proteins (14 vs. } 14 \text { ) }\end{array}$ \\
\hline $\begin{array}{l}\text { Alferink et al. }{ }^{[17]} \\
2019\end{array}$ & Netherlands & $\begin{array}{l}\text { Cohort in elderly } \\
\text { MAFLD by } \\
\text { ultrasound }\end{array}$ & $\begin{array}{l}3882(34 \% \\
\text { MAFLD) }\end{array}$ & $\uparrow 29$ vs. 26 & $\begin{array}{l}\downarrow 35 \mathrm{MET} / \text { week vs. } 44 \\
\mathrm{MET} / \text { week }\end{array}$ & $\downarrow 1996$ vs. 2052 & $\begin{array}{l}=0.45 \text { units/day vs. } \\
0.45 \text { units/day }\end{array}$ & $\begin{array}{l}\% \text { kcal: } \\
\uparrow \text { Fat }(33 \text { vs. } 32) ;[\uparrow \text { SFA }(12 \text { vs. } 11),=\text { MUFA (11 vs. 11), = } \\
\text { PUFA }(6 \text { vs. } 6)] \\
=\text { Carbohydrates }(45 \text { vs. } 49) ;=\text { fiber }(3 \text { vs. } 3)\end{array}$ \\
\hline
\end{tabular}




\begin{tabular}{|c|c|c|c|c|c|c|c|c|}
\hline & & & & & & & & $\uparrow$ Proteins (16 vs. 15 ) \\
\hline $\begin{array}{l}\text { Noureddin et al. }{ }^{[18]} \\
2020\end{array}$ & USA & $\begin{array}{l}\text { Case-control } \\
\text { MAFLD by } \\
\text { Medicare claims } \\
\text { data }\end{array}$ & $\begin{array}{l}2974 \text { NASH } \\
29474 \\
\text { controls }\end{array}$ & $\uparrow 27$ vs. 26 & $\begin{array}{l}\downarrow>0.36 \mathrm{~h} / \text { day: } 20 \% \\
\text { vs. } 23 \%\end{array}$ & $=2122$ vs. 2127 & $\begin{array}{l}\downarrow 2.8 \mathrm{~g} / \text { day vs. } 6.7 \\
\mathrm{~g} / \text { day }\end{array}$ & $\begin{array}{l}\% \mathrm{kcal}: \\
=\text { Fat; }[=\mathrm{SFA},=\mathrm{MUFA},=\mathrm{PUFA}, \uparrow \text { cholesterol }(\mathrm{OR}=1.16)] \\
=\text { Carbohydrates; } \downarrow \text { fiber }(\mathrm{OR}=0.84) \\
\uparrow \text { Red meat }(\mathrm{OR}=1.15) \text { and processed red meat }(\mathrm{OR}=1.18)\end{array}$ \\
\hline
\end{tabular}

Increased intake in cases vs. controls. $\downarrow$ Decreased intake in cases vs. controls. BMI: Body mass index; E: energy; MAFLD: metabolic dysfunction-associated fatty liver disease; MUFA: mono-unsaturated fatty acids; NASH: nonalcoholic steatohepatitis; PUFA: polyunsaturated fatty acids; SFA: saturated fatty acids.

achieving similar weight $\operatorname{loss}^{[24]}$.

Besides how much we eat, when we eat seems to have an effect on the risk for developing MAFLD ${ }^{[25]}$. An overfeeding study provided excessive calories given as sugar at the main meals (hence increasing the size of the meal) or between meals as snacks (hence increasing the frequency of meals). Although the weight gain was not significantly different between groups, the group that increased the frequency of the meals had a dramatic increase in the liver fat content. This was associated with an increase in visceral fat and hepatic de novo lipogenesis (DNL).

More recently, how fast we eat might also have a role in MAFLD. Cross-sectional studies found that eating fast associated with a 4 -fold increased risk for MAFLD $^{[26]}$, particularly in lean subjects ${ }^{[27]}$.

\section{THE ROLE OF CARBOHYDRATES IN THE PATHOGENESIS OF MAFLD}

Epidemiological studies do not favor an association between the proportion of energy intake as carbohydrates and the risk of having MAFLD or steatohepatitis [Table 1]. Similarly, interventional studies with high carbohydrates isoenergetic diets did not result in an increase on body weight or intrahepatic lipid content $^{[28]}$

The type of carbohydrate ingested may modulate the risk of MAFLD, if not in hypercaloric ${ }^{[29-31]}$ at least in isocaloric $\operatorname{diets}^{[32]}$. For example, a small crossover study provided two isocaloric diets with half of the energy from carbohydrates as fructose or almost all as complex carbohydrates (cereals, bread, pasta, rice, and potatoes). The high-fructose group developed an increase in DNL and a significant increase in liver steatosis ${ }^{[33]}$.

\section{Fructose and sugar-sweetened beverages}

Preclinical and interventional human studies showed that, when compared to glucose, fructose supplementation was associated with higher adiposopathy and increased visceral fat, IR, and hypertriglyceridemia, at the expense of an increase in hepatic DNL, despite similar increase in body weight ${ }^{[2,34,35]}$. This is extremely relevant since, although the contribution of DNL for the intrahepatic lipid content is only $5 \%$ in patients without liver steatosis, it increases to $25 \%$ in 
patients with MAFLD ${ }^{[36]}$. In addition, newly synthesized fatty acids are fully saturated, and hence DNLderived fatty acids are potentially more lipotoxic ${ }^{[37]}$. Indeed, studies with rodents showed that fatty acids derived from fructose-driven DNL induced ER stress and cellular injury, which was not observed when the fatty acids overload came directly from the $\operatorname{diet}^{[38]}$.

From a physiological point of view, fructose can promote liver steatosis both directly via DNL and indirectly via DNL feedback inhibition of fatty acids oxidation ${ }^{[39]}$. Indeed, unlike glucose metabolism, which is highly regulated, fructose phosphorylation is not regulated by the hepatic energy status. As such, ingested fructose suffers a first-pass metabolism, in which fructose is retained in the liver not reaching systemic circulation. Ingested glucose, on the other hand, is only partially retained in the liver and can be utilized by peripheral tissues as an energy source for exercising muscle and DNL/storage in the adipose tissue. This results that ingested fructose may act as unlimited substrate for hepatic DNL ${ }^{[40]}$. Additionally, fructose activates SREBP$1 \mathrm{c}$ independently of insulin, with activation of genes involved in $\mathrm{DNL}^{[41]}$. Furthermore, fructose inhibits PPAR- $\alpha$ activity and decreases FGF-21 expression, through a ChREBP-dependent manner ${ }^{[42]}$.

Fructose also depletes ATP in hepatic cells, which promotes an increase in AMP-derived uric acid synthesis ${ }^{[43,44]}$. Uric acid may be a link between fructose consumption and the MS through a decrease in NO bioavailability, as NO is required for the insulin-stimulated glucose uptake. Accordingly, studies in rodents and randomized clinical trials in humans showed that fructose, but not dextrose, induced features of $\mathrm{MS}^{[45,46]}$, which were prevented or reversed by allopurinol, an inhibitor of uric acid synthesis ${ }^{[45,47]}$. Fructose promotes small bowel bacterial overgrowth and increased gut permeability ${ }^{[48]}$, increasing endotoxinemia, which also promotes $\mathrm{IR}^{[42]}$. Lastly, fructose inhibits leptin expression, blunting a satiety response to a meal ${ }^{[49]}$.

Taking all into consideration, it comes with no surprise that different studies showed that, compared to controls, patients with MAFLD consume 2-3 times more fructose ${ }^{[50]}$. Patients with MAFLD with higher fructose consumption are also at increased risk of having steatohepatitis and advanced fibrosis ${ }^{\left[{ }^{[1]}\right]}$. Metaanalyses suggested a dose threshold for the deleterious effects of fructose, with fructose consumption lower than $10 \%$ of energy intake (<50 g/day for a $2000 \mathrm{kcal}$ diet $)$ not inducing weight gain or dyslipidemia ${ }^{[52,53]}$. Animal models also corroborate a threshold effect for fructose-induced MAFLD and liver injury. Indeed, a study feeding rodents with $10 \%, 20 \%$, and $30 \%$ energy from fructose showed a dose-response increase in liver steatosis. Furthermore, fibrosis only developed when fructose consumption was at least $20 \%$ of energy intake ${ }^{[54]}$.

Fructose is a naturally occurring simple sugar present in fruit and honey, but it is mostly consumed as sucrose (a disaccharide that combines one molecule of glucose with one molecule of fructose) and the artificial sweetener high-fructose corn syrup (with a usual ratio of $55 \%$ glucose and $45 \%$ fructose ${ }^{[55]}$. A major source of fructose in the western diet is sugar-sweetened beverages (SSBs) or soft drinks. The average sugar content of SSB is $10 \mathrm{~g} / 100 \mathrm{~mL}$ ( $10 \mathrm{~g}$ for juices, $8.5 \mathrm{~g}$ for tea-based beverages, $5 \mathrm{~g}$ for sports drinks, and $7 \mathrm{~g}$ for energy drinks) ${ }^{[56]}$. Importantly, SSBs, besides fructose, contain other components such as caramel and aspartame, both with proinflammatory and diabetogenic properties. Furthermore, SSBs, unlike solid foods, induce lower satiety and hence promote an increase in caloric ingestion ${ }^{[57]}$.

An interventional study on non-diabetic obese or overweight subjects delivered isocaloric diets with consumption of $1 \mathrm{~L}$ /day of SSB, low-fat milk, aspartame-sweetened drinks, or water for 6 months. At the end of the follow up, body weight was similar, but the sucrose group experienced an increase in visceral adipose tissue, liver and muscle steatosis, and dyslipidemia ${ }^{[58]}$. 
Epidemiological studies showed us that consumption of SSB is associated with an increased risk for central obesity and increased visceral fat ${ }^{[59-62]}, \mathrm{MS}^{[59,63]}$, dyslipidemia ${ }^{[64]}, \mathrm{T}_{2} \mathrm{DM}^{[63,65-67]}$, cardiovascular diseases ${ }^{[63,68]}$, and mortality ${ }^{[69]}$.

SSB consumption is also associated with MAFLD, as shown in different populations, independently of the presence of the MS ${ }^{[12,31,70-72]}$. Two studies from Israel showed that four out of five patients with MAFLD regularly drunk SSB, as opposed to only one out of five controls ${ }^{[70,71]}$. The effect can be seen with intakes $\geq 1$ serving of SSB per week ${ }^{[72]}$. For intakes of $\geq 1$ serving/day, the risk of having MAFLD increases by $50 \%{ }^{[12]}$, liver fibrosis by $250 \%^{[51]}$, and hepatocellular carcinoma by up to 2 -fold ${ }^{[73,74]}$.

Artificially sweetened beverages (ASBs) and 100\% fruit juices seem to have similar dismal effects as SSB, regarding increasing the risk for obesity ${ }^{[75]}$ and $\mathrm{T}_{2} \mathrm{DM}^{[76,77]}$.

We should advise our patients that fruit should be eaten and not drunk. Consumption of $100 \%$ fruit juices increases by $15 \%$ the risk of developing T2DM, whereas whole fruit consumption decreases it. The effect of whole fruit consumption depends on the fruit ingested, with blueberries being associated with a $25 \%$ decrease in the risk of T2DM; grapes, raisins, and prunes by about 10\%; and apples, pears, bananas, and grapefruit by about $5 \%$. As an exception, cantaloupe has been associated with a $10 \%$ increased risk ${ }^{[78]}$. Unlike fruit juices, fruit intake, as a source of fructose, seems to be metabolically beneficial ${ }^{[79]}$. Low doses of fructose consumption paradoxically seem to have a beneficial effect on glucose metabolism, being associated with lower levels of glycated hemoglobin $(\mathrm{HbA} 1 \mathrm{c})^{[53]}$. Indeed, some authors found that a $7.5 \mathrm{~g}$ fructose intake per meal can improve long-term glycemic control in humans, through a decrease in the post-prandial glycemic response to high glycemic index carbohydrates ${ }^{[80]}$. This protective effect is mediated by an increase in the activity of glycogen synthase, shunting glucose for storage as glycogen ${ }^{[81]}$.

ABSs seem to be diabetogenic and steatogenic mainly because their consumption increases appetite ${ }^{[82]}$, but also through their effects on altering gut microbiota ${ }^{[83]}$. It could also be the case of reverse causation, in which patients at increased risk for obesity/T2DM and cardiovascular diseases would be more likely to switch from SSB to ASB in an attempt to control body weight.

Two studies also found that ingestion of $\geq 1$ diet cola/soda per day increases by $40 \%$ the risk of having MAFLD $^{[70,84]}$. Importantly, ASB, similar to SSB, also increases mortality, particularly cardiovascular mortality ${ }^{[85,86]}$.

\section{Fibers}

Fibers can be classified in soluble fibers (present in barley, oats, beans, figs, prunes, and sweet potatoes) and insoluble fibers (present in cereals, whole-wheat bread, lentils, apples, avocado, and strawberries). The former delay gastric emptying, restricting caloric intake, whereas the latter promote satiety and act as prebiotics, for example increasing the abundance of Bifidobacteria and being metabolized by the microbiota to produce short-chain fatty acids ${ }^{[49]}$. Short-chain fatty acids have anti-diabetogenic and anti-inflammatory properties $^{[87]}$.

Interventional studies with fiber-rich diets consistently showed a beneficial effect, decreasing body weight, body fat, and waist circumference, as well as improving insulin sensitivity ${ }^{[8-91]}$.

Epidemiological studies consistently found a protective association between fiber intake and the prevalence of MAFLD ${ }^{[1,14,15,92,93]}$ and steatohepatitis ${ }^{[10]}$. A dietetic interventional study on MAFLD patients, with an 
increase in fiber intake for 6 months was associated with an improvement in liver enzymes and intestinal permeability ${ }^{[94]}$. However, a shorter duration small clinical trial (12 weeks), on prediabetic subjects, failed to find a benefit on liver steatosis ${ }^{[95]}$.

Higher fiber intake also seems to protect from hepatocellular carcinoma. A meta-analysis comprising more than one million participants showed an $8 \%$ decrease in the risk for hepatocellular carcinoma for each $100 \mathrm{~g} /$ day intake of vegetables ${ }^{[96]}$.

\section{THE ROLE OF FATS IN THE PATHOGENESIS OF MAFLD}

Several epidemiological studies showed an association between higher percentage of energy intake as fat and the risk of having MAFLD ${ }^{[1,15,17]}$, even though this association was not consistently observed $\mathrm{d}^{[10,12,14,16,18]}$. Importantly, the type of fat ingested, particularly saturated fat and cholesterol, appears to have a dismal effect on the development and progression of MAFLD ${ }^{[10,15,17,18]}$.

\section{Saturated, polyunsaturated, and monounsaturated fatty acids and trans-fats}

Saturated fatty acids (SFAs), such as palmitic acid, have all carbons in the hydrocarbon backbone connected by single bonds. As a result, the molecules in saturated fat are packed close together; the fat is solid at room temperature and very heat stable. SFAs are present mainly in animal products such as red meat, butter, and whole milk dairy products; some vegetable products such as coconut oil and palm oil; and prepared foods such as deserts and sausages ${ }^{[97]}$. SFAs have the potential to induce dysmetabolism and are toxic to hepatocytes. SFA can induce IR and inflammation, among other mechanisms, through direct binding to TLR-4 and indirectly through the synthesis of diacylglycerol and ceramides ${ }^{[88]}$. SFAs are highly hepatotoxic, inducing oxidative stress, ER stress, and apoptosis on hepatocytes ${ }^{[99-101]}$. SFAs also modulate gut microbiota to assume a more obesogenic and inflammatory phenotype ${ }^{[102,103]}$.

Polyunsaturated fatty acids (PUFAs) have multiple double carbon bonds. PUFAs have anti-steatogenic actions, inhibiting the lipogenic transcription factor SREBP-1c while inducing PPAR- $\alpha$, a regulator of fatty acids oxidation.

SFA intake seems to be associated with cardiovascular diseases ${ }^{[104]}$, with a $10 \%$ decrease of coronary events for every $5 \%$ of energy intake conferred by PUFAs in substitution of SFAs ${ }^{[105]}$. Furthermore, intakes lower than $10 \%$ of energy as SFA decreases IR and dyslipidemia, whereas lower than $7 \%$ does not confer additional benefit and it may even be detrimental ${ }^{[49]}$. Recently, SFAs have also been associated with advanced fibrosis ${ }^{[106]}$ and hepatocellular carcinoma, with an increase of $4 \%$ of liver cancer for each $1 \%$ energy intake from $\mathrm{SFA}^{[107]}$.

Different dietary studies, with iso- or hypercaloric diets supplemented with SFAs or PUFAs, for as short as 3 weeks, consistently found SFAs supplementation, but not PUFAs, to induce an increase in liver fat content, circulating ceramides, markers of lipogenesis as well as IR, and increase in endotoxinemia, despite maintaining stable body fat and visceral adipose tissue depots ${ }^{[108-111]}$.

Although most epidemiological studies did not find an association between dietary PUFA and MAFLD, patients with steatohepatitis seem to present lower PUFA intake ${ }^{[112,113]}$.

PUFAs can be classified as omega-3 ( $\Omega-3)$ or $\Omega-6$ according to the position of the first double carbon bond (counting from the terminal methyl). Examples of $\Omega-6$ PUFAs are linoleic acid and arachidonic acid. They derive from sunflower and meat/eggs and dairy, respectively, and have proinflammatory and prothrombotic 
properties. Examples of $\Omega$-3 PUFAs are eicosapentaenoic acid and docosahexaenoic acid (DHA), and they derive mainly from fatty fish. $\Omega$-3 PUFAs tend to have anti-inflammatory, insulin-sensitizer, and antilipogenic properties ${ }^{[114]}$. Western diets typically contain higher amounts of $\Omega-6$ compared to $\Omega-3$ PUFAs $s^{[115]}$. Patients with MAFLD, compared to controls, tend to present lower hepatic levels of DHA, increased $\Omega-6 / \Omega-3$ ratio, and negative correlation between hepatic $\Omega-3$ PUFAs levels and SREPBP-1c (prolipogenic)/PPAR $\alpha$ (pro-lipolytic) ratio $^{[116,117]}$. Furthermore, compared to controls, patients with steatohepatitis seem to present a higher $\Omega-6 / \Omega-3$ ratio in the diet ${ }^{[11]}$. Lastly, fish consumption appears to be associated with a $35 \%$ reduction and $\Omega$-3 PUFA intake with a $50 \%$ reduction in the risk for hepatocellular carcinoma $^{[118-121]}$.

Supplementation with high doses of $\Omega$-3 PUFAs seems to improve dyslipidemia ${ }^{[122]}$ and cardiovascular morbidity/mortality ${ }^{[123]}$. However, effects on MAFLD were disappointing, with studies only demonstrating benefit in steatosis assessed by ultrasound, for doses of at least $0.83 \mathrm{~g} /$ day $^{[124]}$. Supplementation with $\Omega-3$ PUFAs did not seem to improve liver histology ${ }^{[125,126]}$.

MUFAs, such as oleic acid, only have one double carbon bon and are mainly present in olive oil, avocado, nuts, and seeds. MUFAs are liquid at room temperature and less heat stable than SFAs. MUFAs are known to promote lipid oxidation while protecting from IR and seem to be protective from the MS and cardiovascular diseases ${ }^{[97]}$.

Even though epidemiological studies failed to find an association between dietary MUFA intake and MAFLD, interventional studies in prediabetic and diabetic patients submitted to isocaloric diets with MUFA supplementation achieved a decrease in liver fat content and improvement in hepatic insulin sensitivity ${ }^{[95,127]}$.

Olive oil is a major source of MUFAs. Extra-virgin olive oil contains 70\%-80\% MUFAs and 20\% palmitic acid. It also contains $\alpha$-tocopherol, polyphenols, and other anti-inflammatory and antioxidant phytochemicals ${ }^{[97,128]}$. When refined or heated, olive oil loses its natural compounds; hence, it should not be cooked at high temperature. The FDA recommends the intake of $20 \mathrm{~g} /$ day of extra-virgin olive oil to prevent cardiovascular disease, since it has been shown that each $10 \mathrm{~g}$ per $2000 \mathrm{kcal}$ diet is associated with $7 \%$ decrease in overall and $13 \%$ cardiovascular mortality ${ }^{[29]}$. Regarding MAFLD, three small clinical trials also suggested benefit of dietary olive oil in serum lipid profile and improvement of hepatic steatosis ${ }^{[130-132]}$.

Trans-fatty acids differ from unsaturated fatty acids by having a double bond in the trans instead of cis configuration, making them straighter and resembling the structure of SFA. Trans-fats are abundant in ultra-processed foods such as margarines and fast food. Trans-fatty acids probably have a role in the pathogenesis of MAFLD, since higher intakes of trans-fatty acids seem to be associated with increased risk of having MAFLD ${ }^{[17]}$. In addition, patients with MAFLD tend to present higher serum levels of trans-fatty acids $^{[133]}$. Finally, preclinical studies in rodents suggest that trans-fats are associated with worse MAFLD and worse liver injury ${ }^{[134,135]}$.

Importantly, high trans-fat-containing ultra-processed food intake has recently been shown to be associated with many chronic diseases such as obesity, MS, hypertension, T2DM, cardiovascular diseases, cancer, and mortality ${ }^{[136-140]}$. 


\section{Cholesterol}

Two large epidemiological studies found an association between high cholesterol intake and MAFLD, steatohepatitis, and advanced fibrosis ${ }^{[1,18,106]}$. Dietary cholesterol seems to have higher relevance in lean MAFLD $^{[141]}$. Finally, dietary cholesterol seems to be associated with an increased risk for hepatocellular carcinoma, with a particularly aggressive phenotype, in rodent models ${ }^{[142]}$.

Cholesterol has steatogenic effects, as its oxysterol metabolites are agonists of liver X-receptor- $\alpha$, a transcription factor that increases SREBP-1c expression, and hence $\mathrm{DNL}^{[143]}$. Hepatic free cholesterol is also highly lipotoxic, inducing ER stress, mitochondrial dysfunction, and hepatocyte cell death. It also accumulates in Kupffer cells, inducing a proinflammatory response, as well as in hepatic stellate cells, promoting fibrogenesis ${ }^{[144]}$.

\section{THE ROLE OF PROTEINS IN THE PATHOGENESIS OF MAFLD}

The association between higher protein intake and increased risk for MAFLD is the most consistent finding in dietary epidemiological studies ${ }^{[10,12,14-18]}$. Indeed, the risk of having MAFLD increased around $25 \%$ for each $1 \%$ of energy intake as protein $s^{[16]}$. Data from epidemiological studies, however, conflict with those from interventional studie, suggesting that high-protein diets blunt the steatogenic effect of high-fat diets ${ }^{[145-147]}$. Importantly, those anti-steatogenic effects of high-protein diets were achieved for moderate intakes of proteins (25\% of energy from protein), with no additional benefit for high intakes ( $40 \%$ energy from proteins ${ }^{[148]}$. In addition, high-protein diets seem to improve body composition, increasing lean body mass and decreasing fat mass and waist circumference, as well as increasing muscle endurance ${ }^{[149-151]}$. However, it is also associated with an increase in inflammatory markers possibly through the promotion of gut microbiome dysbiosis ${ }^{[151,152]}$. Other potential negative impacts of high-protein diets are the potential to accelerate the progression or even induce chronic kidney disease in the long run $^{[153]}$. Protein-derived nitrosamine and heterocyclic amines also increase the risk for colorectal cancer ${ }^{[154]}$. Furthermore, studies on rodent animal models suggest that high-protein diets may promote the development of MAFLD with a more inflammatory phenotype $\mathrm{e}^{[155]}$.

Importantly, not all proteins have the same effect on health, with animal protein, as opposed to plant protein, having a detrimental effect. Indeed, ingestion of animal proteins seems to be associated with obesity, MS, and T2DM, while plant protein tends to be protective ${ }^{[156,157]}$. Plant protein intake is also associated with a decrease in all-cause and cardiovascular-related mortality ${ }^{[158-160]}$. Similarly, regarding MAFLD, epidemiological studies found animal proteins to increase its risk, while plant proteins to decrease $\mathrm{it}^{[16,17]}$. The difference between plant and animal proteins may relate to the nutritional characteristics of foods containing those proteins. For example, animal proteins usually come from foods that have high index of SFA, whereas plant proteins come from foods that contain fibers and phenolic compounds ${ }^{[161,162]}$. Plant and animal proteins also have different amino acid compositions, with plant proteins being enriched in arginine, glycine, and glutamate/glutamine while animal proteins in branched-chain amino acids (BCAAs). Arginine provides substrate for NO, which has vasodilator properties and beneficial effects on endothelial function and other cardiometabolic functions. Glycine and glutamine potentiate the action of insulin and lower blood pressure. On the other hand, BCAAs are associated with obesity, IR, and cardiovascular diseases ${ }^{[161]}$.

Recently, it has become clear that the type of animal protein has a role in cardiometabolic health, with red meat being the most deleterious one. Indeed, large epidemiological studies showed a positive association between red meat ingestion, and a negative one between white meat (e.g., poultry and fish), and all-cause and cancer-, cardiovascular-, and liver-related mortality ${ }^{[163]}$. Similar associations were found for chronic 
liver disease and hepatocellular carcinoma ${ }^{[120,12,164]}$. Epidemiological studies unraveled an association between meat and processed meat consumption and MAFLD ${ }^{[12,17,165,166]}$, with intakes higher that $36 \mathrm{~g} /$ day of meat protein (equivalent to $110 \mathrm{~g}$ of red meat) being associated with more than 3.5 -fold increased risk ${ }^{[12]}$. Importantly, unhealthy cooking of red meat, such as fried or grilled and broiled to well-done level, are also associated with further increase in IR and the risk of having MAFLD. Unhealthy cooking increases the generation of heterocyclic amines, which promote inflammation and oxidative stress, having diabetogenic and steatogenic properties by itself ${ }^{[166]}$. Heterocyclic amines are also mutagenic compounds and can be associated with some types of cancer such as breast and colorectal cancer ${ }^{[167]}$. Additionally, unhealthy cooking of red meat increases the generation of advanced glycation end products ${ }^{[168]}$, which have also been associated with MAFLD ${ }^{[169]}$.

Regarding plant proteins, interventional studies with high-soy diets have suggested a beneficial effect in patients with MAFLD, resulting in a decrease in liver enzymes and the oxidative stress marker malondialdehyde ${ }^{[170]}$. However, those effects on liver enzymes were not supported by a recent metaanalysis ${ }^{[171]}$. Importantly, research on the cardiometabolic effects of soy protein only found benefit for intakes higher than $25 \mathrm{~g} /$ day, which are extremely difficult to achieve $\mathrm{e}^{[172]}$. For example, a community with particularly high soy consumption, the Adventist vegans in the United States on average only consume $13 \mathrm{~g} / \mathrm{day}^{[173]}$.

\section{ALCOHOL AND MAFLD - MORE THAN THE SUM}

There is consensus that more than 2 drinks/day ( $20 \mathrm{~g}$ of alcohol) in women and 3 drinks/day ( $30 \mathrm{~g}$ of alcohol) in men are potentially hepatotoxic. There is still no consensus on the effect of lower amounts of alcohol intake (i.e., moderate alcohol consumption) in patients with MAFLD. Several epidemiological studies and meta-analyses suggested that moderate alcohol consumption could be protective for the development of MAFLD, steatohepatitis, and advanced fibrosis ${ }^{[174-181]}$. Such studies, however, have been criticized for having methodological flaws, not taking into consideration alcohol patterns, with potential underestimation of alcohol consumption, and incomplete adjustment for confounders ${ }^{[182]}$. Furthermore, that protective effect was observed for wine but not for beer and was lost with binge drinking (defined as drinking more than four drinks for women or five drinks for men on one occasion) $)^{[177,183]}$. Indeed, binge drinking at least monthly is associated with progression of liver fibrosis in MAFLD patients ${ }^{[184]}$, and binge drinking weekly increased more than 3 -fold the risk for decompensated liver disease ${ }^{[185]}$. Importantly, several recent cross-sectional ${ }^{[186,187]}$ and longitudinal studies were in disagreement with previous studies and did find a positive association between moderate drinking and progression of steatohepatitis and liver fibrosis in MAFLD patients ${ }^{[188-190]}$.

Before we recommend moderate alcohol intake for patients with MAFLD, we must keep in mind that there is a synergistic effect for the development of liver disease among alcohol consumption, obesity, MS, and $\mathrm{T}_{2} \mathrm{DM}^{[191]}$. Indeed, whereas in subjects with normal weight there is no association between moderate alcohol intake and elevated liver enzymes, overweight who drink $>2$ drinks/day and obese who drink $\geq 1$ drink/day have an increased risk for altered liver enzymes ${ }^{[192-194]}$. In addition, in overweight, drinking $>1 \mathrm{drink} /$ week was associated with a 2 -fold increased risk for chronic liver disease ${ }^{[195]}$. Moderate alcohol consumption and T2DM synergistically increase the risk for advanced fibrosis in MAFLD ${ }^{[187]}$. Obesity and any alcohol use have a synergistic effect not only in the risk for liver cirrhosis but also for hepatocellular carcinoma ${ }^{[196,197]}$. Furthermore, for patients with MAFLD-associated cirrhosis, any alcohol intake seems to be associated with a 3.5-fold increased risk of hepatocellular carcinoma ${ }^{[198]}$ and should be highly discouraged. 
Regarding mortality, a recent study suggested that regular drinking less than 1.5 drinks/day was associated with a $40 \%$ decreased mortality in patients with MAFLD, but drinking higher than that with a $45 \%$ increased mortality ${ }^{[199]}$. Of note, the beneficial effect on mortality was only verified in men and patients without fibrosis (assessed by FIB-4 $<1.79)^{[199]}$. Importantly, obese patients who drink $>1$ drink/week presented a 5fold increased liver-related mortality ${ }^{[195]}$.

Lastly, recently the J-shape effect of alcohol intake on mortality, in the general population, has been challenged. In fact, despite that the J-shape may occur for cardiovascular- and T2DM-associated mortality, overall, because alcohol intake is linearly associated with other causes of mortality such as cancer and infections, any alcohol intake is linearly associated with progressively increased mortality ${ }^{[200]}$. Of note, the beneficial arm in the J-curve for cardiovascular mortality was lost in smokers.

\section{COFFEE SEEMS PROTECTIVE FOR MAFLD}

Unlike alcohol, data on coffee seem more consensual in decreasing around 30\% the risk of developing MAFLD and progressive fibrosis ${ }^{[201,202]}$. There seems to be a non-linear dose-response for coffee intake, with decreased risk for MAFLD and liver fibrosis when drinking at least three coffees/day ${ }^{[203,204]}$.

Coffee contains different biologically active compounds such as antioxidant chlorogenic acids, kahweol, cafestol, and caffeine. The protective effect of coffee on liver health appears to be specific for coffee and not shared with other caffeinated drinks such as tea, soft drinks, and energetic drinks ${ }^{[205]}$.

Not all coffee seems to have the same protective effect, with protection from MAFLD described for filtrated/regular coffee (which better preserves its chlorogenic acids) but not for espresso coffee (obtained from high-pressure boiling water through a column of coffee, which can modify several of its components $\left.{ }^{[206]}\right)^{[207]}$. Decaffeinated coffee has shown the same beneficial effect on MAFLD as compared to regular coffee ${ }^{[208]}$.

Finally, a similar non-linear response was found for hepatocellular carcinoma, with a decreased risk for subjects who drank at least two coffees/day (or decaffeinated coffees) ${ }^{[209]}$.

\section{EATING PATTERNS AND MAFLD}

Different diets have been proposed for the management of MAFLD, the most studied ones being the Mediterranean diet (MD), the Dietary Approaches to Stop Hypertension (DASH) diet, and the intermittent fasting diet.

MD has its origins in the traditional diet from Mediterranean countries and is characterized by a high consumption of plant-based foods such as vegetables (up to 6 servings/day), fruits (up to 3 servings/day), whole grains, seeds, nuts, and legumes. It is relatively low in carbohydrates ( $40 \%$ of the calories), particularly sugars and refined carbohydrates ${ }^{[210]}$. It allows moderate consumption of protein-source foods such as fish and poultry, but it is scarce in red meat. MD is rich in MUFAs, primarily from olive oil (which is the main added lipid) and olives, and restricts fatty dairy products. MD is particularly enriched in fibers and provides a high $\Omega-3 / \Omega-6$ ratio. It also allows for moderate drinking, particularly red wine $\mathrm{e}^{[21,212]}$.

Epidemiological studies found that higher adherence to MD was associated with lower severity of hepatic steatosis and lower likelihood of steatohepatitis, liver fibrosis, and hepatocellular carcinoma ${ }^{[213-217]}$. Interventional studies showed that consuming MD was associated with an improvement in liver enzymes, 
steatosis, liver stiffness, and lipid profile, even without weight loss ${ }^{[218-227]}$. We still need long-term trials to understand the role of MD on liver histopathology. Importantly, high adherence to MD has also been associated with decreased all-cause and cardiovascular mortality ${ }^{[228]}$.

The DASH diet was developed in the early 1990s as an intervention to manage arterial hypertension, emphasizing a low sodium intake and the consumption of minimal processed fresh foods ${ }^{[229]}$. Two epidemiological studies found that high adherence to the DASH diet was associated with lower risk of having MAFLD ${ }^{[230,231]}$. A small randomized controlled trial on MAFLD also suggested that engaging a DASH diet for 8 weeks resulted in improvement in liver enzymes ${ }^{[232]}$.

The newest diet is time-restricted feeding as a form of intermittent fasting, which restricts the eating window, without emphasizing calorie restriction. This diet seems effective in decreasing body weight ${ }^{[233]}$, whereas many authors disclaimed that the effect is resultant of an actual calorie restriction. A recent metaanalysis, in patients with MAFLD, found intermittent fasting to be beneficial in weight loss and liver enzymes ${ }^{[234]}$, even though it failed to demonstrate additional metabolic benefit compared to calorierestriction diets ${ }^{[235]}$. Long-term feasibility and stronger endpoints require further research. For the time being, it is wise to advise against this diet for patients with MAFLD-associated cirrhosis, due to the effect of fasting on sarcopenia development in those patients.

\section{RECOMMENDATIONS}

The recommendations from the international guidelines ${ }^{[236-240]}$ are summarized in Table 2.

Patients should be clearly informed regarding the severity of their illness and its prognostic consequences, but also the reversibility that could be expected when engaging weight loss-directed lifestyle behaviors ${ }^{[241]}$. Exercise recommendations should always be a part of the lifestyle changes advised, keeping in mind that the benefits of exercise occur even without weight loss ${ }^{[242]}$.

Simple recommendations should be given [Table 3], particularly the advice to eat less ${ }^{[14]}$, tailoring the weight loss according to the severity of liver disease: $3 \%-5 \%$ if isolated steatosis, $7 \%$ if steatohepatitis, and $10 \%$ when fibrosis is present ${ }^{[8]}$.

Regarding the macronutrient composition, daily intake of energy should be 45\%-65\% from carbohydrates, 20\%-35\% from fat, and 10\%-35\% from proteins ${ }^{[243]}$. Not all carbohydrates are the same. Added sugar should be restricted to no more than $5 \%-10 \%$ of daily calories ${ }^{[244]}$, while fibers ingestion should be at least $25 \mathrm{~g} /$ day in women and $38 \mathrm{~g} /$ day in men, particularly promoting a high intake of vegetables and legumes. A practical tip is to suggest vegetable soup as a starter in every meal. Regarding fruit intake, it should be no more than 2-3 portions per day and should be eaten as whole fruit rather than drunk as fruit juice. Patients should abstain from drinking SSB, including ASB. Patients should also be advised on the type of fat they should consume, avoiding processed food, desserts, and fast food (high in saturated and trans-fats), while electing MUFA-rich olive oil as the preferred oil. Recommended olive oil intake is $20 \mathrm{~g} /$ day, avoiding cooking it at high temperatures. To achieve a good $\Omega$-3/ $\Omega-6$ PUFA ratio (minimum $\Omega$-3 PUFA intake of 0.35-0.40 g/day), prefer fish to meat, eating 2-3 portions of fatty fish per week. Red meat meals should not surpass three meals per week and may be substituted for plant proteins (e.g., soy).

Coffee, including decaffeinated coffee, should not be restricted, and two coffees/day seem to help prevent hepatocellular carcinoma, while three coffees/day prevent steatohepatitis and fibrosis. 
Table 2. International Guidelines on diet for patients with MAFLD

\begin{tabular}{|c|c|c|c|c|c|}
\hline & AGA $2021^{[236]}$ & AASLD $2018^{[237]}$ & $\begin{array}{l}\text { EASL }_{2016^{1238]}}^{\text {EASD, EASO }} \\
\end{array}$ & NICE $2016^{[239]}$ & WGO $2014^{[240]}$ \\
\hline Energy restriction & $\begin{array}{l}\text { Hypocaloric: } 1200 \text { - } \\
1500 \mathrm{kcal} / \text { day or } \downarrow \text { from } \\
\text { baseline } 500-1000 \mathrm{kcal} / \text { day }\end{array}$ & $\begin{array}{l}\text { Hypocaloric: } \downarrow \text { from } \\
\text { baseline } 500 \text { - } \\
1000 \text { kcal/day }\end{array}$ & $\begin{array}{l}\text { Hypocaloric: } \downarrow \text { from } \\
\text { baseline } 500 \text { - } \\
1000 \mathrm{kcal} / \text { day }\end{array}$ & $\begin{array}{l}\text { Hypocaloric: } \downarrow \text { from } \\
\text { baseline } \\
600 \mathrm{kcal} / \text { day }\end{array}$ & $\begin{array}{l}\text { Hypocaloric: } \downarrow \\
\text { calories intake } \\
25 \%\end{array}$ \\
\hline $\begin{array}{l}\text { Weight loss } \\
\text { target }\end{array}$ & $\begin{array}{l}\geq 5 \% \text { if steatosis } \\
\geq 7 \% \text { if } \mathrm{NASH} \\
\geq 10 \% \text { if fibrosis }\end{array}$ & $\begin{array}{l}3 \%-5 \% \text { if steatosis } \\
7 \%-10 \% \text { if } \mathrm{NASH} \pm \\
\text { fibrosis }\end{array}$ & $7 \%-10 \%$ & - & $5 \%-10 \%$ \\
\hline $\begin{array}{l}\text { Macronutrient } \\
\text { composition }\end{array}$ & $\begin{array}{l}\text { Minimize SFA, } \downarrow \text { red and } \\
\text { processed meat }\end{array}$ & Less relevant & $\begin{array}{l}\text { Low to moderate fat and } \\
\text { moderate to high } \\
\text { carbohydrates }\end{array}$ & Low fat diets & $\begin{array}{l}\text { Avoid trans-fats } \\
\uparrow \Omega-3 / \Omega-6 \text { PUFA }\end{array}$ \\
\hline Fructose intake & $\begin{array}{l}\text { Avoid fructose commercially } \\
\text { produced }\end{array}$ & - & $\begin{array}{l}\text { Avoid fructose-containing } \\
\text { foods and beverages }\end{array}$ & - & $\begin{array}{l}\text { Avoid fructose } \\
\text { and soft drinks }\end{array}$ \\
\hline Dietary pattern & Mediterranean diet & Mediterranean diet? & Mediterranean diet & - & - \\
\hline Alcohol intake & $\begin{array}{l}\text { Restrict. Abolish in smokers } \\
\text { (current or former) }\end{array}$ & Insufficient data & $\begin{array}{l}<30 \mathrm{~g} / \text { day in men and }< \\
20 \mathrm{~g} / \text { day in women. } \\
\text { Abolish if cirrhosis }\end{array}$ & $<14$ drinks/week & - \\
\hline Coffee intake & - & - & No liver limitations & - & - \\
\hline
\end{tabular}

$\uparrow$ Increase. $\downarrow$ Decrease. AGA: American Gastroenterological Association; AASLD: American Association for the Study of the Liver; EASL: European Association for the Study of the Liver; EASD: European Association for the Study of Diabetes; EASO: European Association for the Study of Obesity; NASH: nonalcoholic steatohepatitis; NICE: National Institute for Health and Care Excellence; PUFA: polyunsaturated fatty acids; SFA: saturated fatty acids; WGO: World Gastroenterology Organization.

Table 3. Simple dietary recommendations for patients with MAFLD

\begin{tabular}{|c|c|}
\hline Avoid/do not or drink or eat & May/should drink or eat \\
\hline $\begin{array}{l}\text { - Soft drinks } \\
\text { - Fruit juices } \\
\text { - Alcohol (no more than 1-2 drinks/day and total abstinence if smoker, obese or with } \\
\text { liver cirrhosis) }\end{array}$ & - Coffee (2-3 servings/day) \\
\hline $\begin{array}{l}\text { - Processed fruits } \\
\text { - Sugar-added fruits (no more than 1-2 servings/week) } \\
\text { - Animal-origin fat/butter } 2-3 \text { servings/week) }\end{array}$ & $\begin{array}{l}\text { - Fresh fruits ( } 3 \text { servings/day); nuts weekly } \\
\text { - Vegetables and legumes ( } 6 \text { servings/day) } \\
\text { - Unrefined cereals ( } 8 \text { servings/day) } \\
\text { - Fish ( } 4-6 \text { servings/week); poultry/egg (2-4 } \\
\text { servings/week) } \\
\text { - Olive oil ( } 20 \text { g/day) } \\
\text { - Low-fat milk, cheese or yogurt ( } 2-3 \text { servings/day) }\end{array}$ \\
\hline
\end{tabular}

While there are still not enough data to advise regarding moderate alcohol consumption in patients with MAFLD, it should be strongly advised against in patients with liver cirrhosis, obese, and smokers (current or former).

Two dietary patterns that seem to promote improvement of MAFLD and that incorporate the above recommendations are the Mediterranean and the DASH diet, and they should be considered when advising patients.

\section{CONCLUSIONS}

MAFLD is associated with adiposopathy and energy surplus, conditions that are the result of an imbalance between the energy intake and the energy expenditure. As such, what one eats and how much one eats, in harmony with individual metabolism and physical activity, are clearly the basis of the pathophysiology of MAFLD. Despite this intuitive aphorism, it is difficult to scrutinize the role of diet and individualize diet components in the development and progression of MAFLD. This relation is even more intricate, as we know today that our genetics and gut microbiota modulate the way diet programs our metabolism. 
Having all that in mind, we can still safely advise MAFLD patients to "eat less" to promote a tailored weight loss according to the severity of their overweight and liver disease. Dietary recommendations should be provided by a specialized multidisciplinary team, with dedicated dietitians, and psychological cognitivebehavioral support as needed. Secondly, we should advise patients to "eat better", advertising a Mediterranean-like diet, favoring unprocessed fresh foods and fish, in detriment to fast foods, sugar-added foods, and trans-fat-rich foods including red meat. Water is the best drink to promote, and there should be no place for sugary or artificially sweetened drinks. If no other contraindication, coffee might be beneficial in preventing progression of liver disease and hepatocellular carcinoma. While the effects of moderate alcohol intake are still controversial, it should be strongly discouraged for patients with liver cirrhosis, obesity, or smokers.

\section{DECLARATIONS}

\section{Authors' contributions}

The author contributed solely to the article.

\section{Availability of data and materials}

Not applicable.

\section{Financial support and sponsorship}

None.

\section{Conflicts of interest}

The author declared that there are no conflicts of interest.

\section{Ethical approval and consent to participate}

Not applicable.

\section{Consent for publication}

Not applicable.

\section{Copyright}

(c) The Author(s) 2021.

\section{REFERENCES}

1. Jew S, AbuMweis SS, Jones PJ. Evolution of the human diet: linking our ancestral diet to modern functional foods as a means of chronic disease prevention. J Med Food 2009;12:925-34. DOI PubMed

2. Younossi ZM, Stepanova M, Younossi Y, et al. Epidemiology of chronic liver diseases in the USA in the past three decades. Gut 2020;69:564-8. DOI PubMed

3. Goldberg D, Ditah IC, Saeian K, et al. Changes in the prevalence of hepatitis C virus infection, nonalcoholic steatohepatitis, and alcoholic liver disease among patients with cirrhosis or liver failure on the waitlist for liver transplantation. Gastroenterology 2017;152:1090-9.e1. DOI PubMed PMC

4. Noureddin M, Vipani A, Bresee C, et al. NASH leading cause of liver transplant in women: updated analysis of indications for liver transplant and ethnic and gender variances. Am J Gastroenterol 2018;113:1649-59. DOI PubMed

5. Kim D, Konyn P, Sandhu KK, Dennis BB, Cheung AC, Ahmed A. Metabolic dysfunction-associated fatty liver disease is associated with increased all-cause mortality in the United States. J Hepatol 2021. DOI PubMed

6. Eslam M, Newsome PN, Sarin SK, et al. A new definition for metabolic dysfunction-associated fatty liver disease: an international expert consensus statement. J Hepatol 2020;73:202-9. DOI PubMed

7. Neuschwander-Tetri BA. Therapeutic landscape for NAFLD in 2020. Gastroenterology 2020;158:1984-98.e3. DOI PubMed

8. Romero-Gómez M, Zelber-Sagi S, Trenell M. Treatment of NAFLD with diet, physical activity and exercise. J Hepatol 2017;67:82946. DOI PubMed

9. Cizza G, Rother KI. Was Feuerbach right: are we what we eat? J Clin Invest 2011;121:2969-71. DOI PubMed PMC

10. Musso G, Gambino R, De Michieli F, et al. Dietary habits and their relations to insulin resistance and postprandial lipemia in nonalcoholic steatohepatitis. Hepatology 2003;37:909-16. DOI PubMed 
11. Cortez-Pinto H, Jesus L, Barros H, Lopes C, Moura MC, Camilo ME. How different is the dietary pattern in non-alcoholic steatohepatitis patients? Clin Nutr 2006;25:816-23. DOI PubMed

12. Zelber-Sagi S, Nitzan-Kaluski D, Goldsmith R, et al. Long term nutritional intake and the risk for non-alcoholic fatty liver disease (NAFLD): a population based study. J Hepatol 2007;47:711-7. DOI PubMed

13. Jia Q, Xia Y, Zhang Q, et al. Dietary patterns are associated with prevalence of fatty liver disease in adults. Eur J Clin Nutr 2015;69:914-21. DOI PubMed

14. Wehmeyer MH, Zyriax BC, Jagemann B, et al. Nonalcoholic fatty liver disease is associated with excessive calorie intake rather than a distinctive dietary pattern. Medicine (Baltimore) 2016;95:e3887. DOI PubMed PMC

15. Cheng Y, Zhang K, Chen Y, et al. Associations between dietary nutrient intakes and hepatic lipid contents in NAFLD patients quantified by ${ }^{1} \mathrm{H}-\mathrm{MRS}$ and dual-echo MRI. Nutrients 2016;8:527. DOI PubMed PMC

16. Rietman A, Sluik D, Feskens EJM, Kok FJ, Mensink M. Associations between dietary factors and markers of NAFLD in a general Dutch adult population. Eur J Clin Nutr 2018;72:117-23. DOI PubMed

17. Alferink LJ, Kiefte-de Jong JC, Erler NS, et al. Association of dietary macronutrient composition and non-alcoholic fatty liver disease in an ageing population: the Rotterdam Study. Gut 2019;68:1088-98. DOI PubMed

18. Noureddin M, Zelber-Sagi S, Wilkens LR, et al. Diet associations with nonalcoholic fatty liver disease in an ethnically diverse population: the multiethnic cohort. Hepatology 2020;71:1940-52. DOI PubMed PMC

19. Heilbronn LK, Coster AC, Campbell LV, et al. The effect of short-term overfeeding on serum lipids in healthy humans. Obesity (Silver Spring) 2013;21:E649-59. DOI PubMed

20. Sevastianova K, Santos A, Kotronen A, et al. Effect of short-term carbohydrate overfeeding and long-term weight loss on liver fat in overweight humans. Am J Clin Nutr 2012;96:727-34. DOI PubMed

21. Sobrecases H, Lê KA, Bortolotti M, et al. Effects of short-term overfeeding with fructose, fat and fructose plus fat on plasma and hepatic lipids in healthy men. Diabetes Metab 2010;36:244-6. DOI PubMed

22. Haufe S, Engeli S, Kast P, et al. Randomized comparison of reduced fat and reduced carbohydrate hypocaloric diets on intrahepatic fat in overweight and obese human subjects. Hepatology 2011;53:1504-14. DOI PubMed

23. Sacks FM, Bray GA, Carey VJ, et al. Comparison of weight-loss diets with different compositions of fat, protein, and carbohydrates. N Engl J Med 2009;360:859-73. DOI PubMed PMC

24. Kirk E, Reeds DN, Finck BN, Mayurranjan SM, Patterson BW, Klein S. Dietary fat and carbohydrates differentially alter insulin sensitivity during caloric restriction. Gastroenterology 2009;136:1552-60. DOI PubMed PMC

25. Koopman KE, Caan MW, Nederveen AJ, et al. Hypercaloric diets with increased meal frequency, but not meal size, increase intrahepatic triglycerides: a randomized controlled trial. Hepatology 2014;60:545-53. DOI

26. Takahashi F, Hashimoto Y, Kawano R, et al. Eating fast is associated with nonalcoholic fatty liver disease in men but not in women with type 2 diabetes: a cross-sectional study. Nutrients 2020;12:2174. DOI

27. Lee S, Ko BJ, Gong Y, et al. Self-reported eating speed in relation to non-alcoholic fatty liver disease in adults. Eur J Nutr 2016;55:327-33. DOI PubMed

28. Lê KA, Faeh D, Stettler R, et al. A 4-wk high-fructose diet alters lipid metabolism without affecting insulin sensitivity or ectopic lipids in healthy humans. Am J Clin Nutr 2006;84:1374-9. DOI PubMed

29. Silbernagel G, Machann J, Unmuth S, et al. Effects of 4-week very-high-fructose/glucose diets on insulin sensitivity, visceral fat and intrahepatic lipids: an exploratory trial. Br J Nutr 2011;106:79-86. DOI PubMed

30. Sock ET, Lê KA, Ith M, Kreis R, Boesch C, Tappy L. Effects of a short-term overfeeding with fructose or glucose in healthy young males. Br J Nutr 2010;103:939-43. DOI PubMed

31. Chung M, Ma J, Patel K, Berger S, Lau J, Lichtenstein AH. Fructose, high-fructose corn syrup, sucrose, and nonalcoholic fatty liver disease or indexes of liver health: a systematic review and meta-analysis. Am J Clin Nutr 2014;100:833-49. DOI PubMed PMC

32. Johnston RD, Stephenson MC, Crossland H, et al. No difference between high-fructose and high-glucose diets on liver triacylglycerol or biochemistry in healthy overweight men. Gastroenterology 2013;145:1016-25.e2. DOI PubMed

33. Schwarz JM, Noworolski SM, Wen MJ, et al. Effect of a high-fructose weight-maintaining diet on lipogenesis and liver fat. J Clin Endocrinol Metab 2015;100:2434-42. DOI PubMed PMC

34. Stanhope KL, Schwarz JM, Keim NL, et al. Consuming fructose-sweetened, not glucose-sweetened, beverages increases visceral adiposity and lipids and decreases insulin sensitivity in overweight/obese humans. J Clin Invest 2009;119:1322-34. DOI PubMed PMC

35. Geidl-Flueck B, Hochuli M, Németh Á, et al. Fructose- and sucrose- but not glucose-sweetened beverages promote hepatic de novo lipogenesis: a randomized controlled trial. J Hepatol 2021;75:46-54. DOI PubMed

36. Donnelly KL, Smith CI, Schwarzenberg SJ, Jessurun J, Boldt MD, Parks EJ. Sources of fatty acids stored in liver and secreted via lipoproteins in patients with nonalcoholic fatty liver disease. J Clin Invest 2005;115:1343-51. DOI PubMed PMC

37. Neuschwander-Tetri BA. Carbohydrate intake and nonalcoholic fatty liver disease. Curr Opin Clin Nutr Metab Care 2013;16:446-52. DOI PubMed

38. Ren LP, Chan SM, Zeng XY, et al. Differing endoplasmic reticulum stress response to excess lipogenesis versus lipid oversupply in relation to hepatic steatosis and insulin resistance. PLoS One 2012;7:e30816. DOI PubMed PMC

39. Cox CL, Stanhope KL, Schwarz JM, et al. Consumption of fructose-sweetened beverages for 10 weeks reduces net fat oxidation and energy expenditure in overweight/obese men and women. Eur J Clin Nutr 2012;66:201-8. DOI PubMed PMC

40. Bortolotti M, Dubuis J, Schneiter P, Tappy L. Effects of dietary protein on lipid metabolism in high fructose fed humans. Clin Nutr 2012;31:238-45. DOI PubMed 
41. Matsuzaka T, Shimano H, Yahagi N, et al. Insulin-independent induction of sterol regulatory element-binding protein-1c expression in the livers of streptozotocin-treated mice. Diabetes 2004;53:560-9. DOI PubMed

42. Hannou SA, Haslam DE, McKeown NM, Herman MA. Fructose metabolism and metabolic disease. J Clin Invest 2018;128:545-55. DOI PubMed PMC

43. Johnson RJ, Perez-Pozo SE, Sautin YY, et al. Hypothesis: could excessive fructose intake and uric acid cause type 2 diabetes? Endocr Rev 2009;30:96-116. DOI PubMed PMC

44. Abdelmalek MF, Lazo M, Horska A, et al; Fatty Liver Subgroup of Look AHEAD Research Group. Higher dietary fructose is associated with impaired hepatic adenosine triphosphate homeostasis in obese individuals with type 2 diabetes. Hepatology 2012;56:952-60. DOI PubMed PMC

45. Nakagawa T, Hu H, Zharikov S, et al. A causal role for uric acid in fructose-induced metabolic syndrome. Am J Physiol Renal Physiol 2006;290:F625-31. DOI PubMed

46. Ackerman Z, Oron-Herman M, Grozovski M, et al. Fructose-induced fatty liver disease: hepatic effects of blood pressure and plasma triglyceride reduction. Hypertension 2005;45:1012-8. DOI PubMed

47. Perez-Pozo SE, Schold J, Nakagawa T, Sánchez-Lozada LG, Johnson RJ, Lillo JL. Excessive fructose intake induces the features of metabolic syndrome in healthy adult men: role of uric acid in the hypertensive response. Int J Obes (Lond) 2010;34:454-61. DOI PubMed

48. Spruss A, Bergheim I. Dietary fructose and intestinal barrier: potential risk factor in the pathogenesis of nonalcoholic fatty liver disease. J Nutr Biochem 2009;20:657-62. DOI PubMed

49. Ullah R, Rauf N, Nabi G, et al. Role of nutrition in the pathogenesis and prevention of non-alcoholic fatty liver disease: recent updates. Int J Biol Sci 2019;15:265-76. DOI PubMed PMC

50. Ouyang X, Cirillo P, Sautin Y, et al. Fructose consumption as a risk factor for non-alcoholic fatty liver disease. $J$ Hepatol 2008;48:993-9. DOI PubMed PMC

51. Abdelmalek MF, Suzuki A, Guy C, et al; Nonalcoholic Steatohepatitis Clinical Research Network. Increased fructose consumption is associated with fibrosis severity in patients with nonalcoholic fatty liver disease. Hepatology 2010;51:1961-71. DOI PubMed PMC

52. Sievenpiper JL, Carleton AJ, Chatha S, et al. Heterogeneous effects of fructose on blood lipids in individuals with type 2 diabetes: systematic review and meta-analysis of experimental trials in humans. Diabetes Care 2009;32:1930-7. DOI PubMed PMC

53. Livesey G, Taylor R. Fructose consumption and consequences for glycation, plasma triacylglycerol, and body weight: meta-analyses and meta-regression models of intervention studies. Am J Clin Nutr 2008;88:1419-37. DOI PubMed

54. Fakhoury-Sayegh N, Trak-Smayra V, Sayegh R, et al. Fructose threshold for inducing organ damage in a rat model of nonalcoholic fatty liver disease. Nutr Res 2019;62:101-12. DOI PubMed

55. DiStefano JK. Fructose-mediated effects on gene expression and epigenetic mechanisms associated with NAFLD pathogenesis. Cell Mol Life Sci 2020;77:2079-90. DOI PubMed PMC

56. Jin C, Lin L, Li C, et al. The sugar and energy in non-carbonated sugar-sweetened beverages: a cross-sectional study. BMC Public Health 2019;19:1141. DOI PubMed PMC

57. Malik VS, Hu FB. Sugar-sweetened beverages and cardiometabolic health: an update of the evidence. Nutrients 2019;11:1840. DOI PubMed PMC

58. Maersk M, Belza A, Stødkilde-Jørgensen H, et al. Sucrose-sweetened beverages increase fat storage in the liver, muscle, and visceral fat depot: a 6-mo randomized intervention study. Am J Clin Nutr 2012;95:283-9. DOI PubMed

59. Mattei J, Malik V, Hu FB, Campos H. Substituting homemade fruit juice for sugar-sweetened beverages is associated with lower odds of metabolic syndrome among Hispanic adults. J Nutr 2012;142:1081-7. DOI PubMed PMC

60. Odegaard AO, Choh AC, Czerwinski SA, Towne B, Demerath EW. Sugar-sweetened and diet beverages in relation to visceral adipose tissue. Obesity (Silver Spring) 2012;20:689-91. DOI PubMed PMC

61. Ma J, Sloan M, Fox CS, et al. Sugar-sweetened beverage consumption is associated with abdominal fat partitioning in healthy adults. J Nutr 2014;144:1283-90. DOI PubMed PMC

62. Ma J, McKeown NM, Hwang SJ, Hoffmann U, Jacques PF, Fox CS. Sugar-sweetened beverage consumption is associated with change of visceral adipose tissue over 6 years of follow-up. Circulation 2016;133:370-7. DOI PubMed PMC

63. Bray GA, Popkin BM. Dietary sugar and body weight: have we reached a crisis in the epidemic of obesity and diabetes? Diabetes Care 2014;37:950-6. DOI PubMed

64. Aeberli I, Gerber PA, Hochuli M, et al. Low to moderate sugar-sweetened beverage consumption impairs glucose and lipid metabolism and promotes inflammation in healthy young men: a randomized controlled trial. Am J Clin Nutr 2011;94:479-85. DOI PubMed

65. Schulze MB, Manson JE, Ludwig DS, et al. Sugar-sweetened beverages, weight gain, and incidence of type 2 diabetes in young and middle-aged women. JAMA 2004;292:927-34. DOI PubMed

66. Pan A, Malik VS, Schulze MB, Manson JE, Willett WC, Hu FB. Plain-water intake and risk of type 2 diabetes in young and middleaged women. Am J Clin Nutr 2012;95:1454-60. DOI PubMed PMC

67. Siegel KR, Echouffo-Tcheugui JB, Ali MK, Mehta NK, Narayan KM, Chetty V. Societal correlates of diabetes prevalence: an analysis across 94 countries. Diabetes Res Clin Pract 2012;96:76-83. DOI PubMed

68. Koning L, Malik VS, Kellogg MD, Rimm EB, Willett WC, Hu FB. Sweetened beverage consumption, incident coronary heart disease, and biomarkers of risk in men. Circulation 2012;125:1735-41, S1. DOI PubMed PMC

69. Zhang YB, Jiang YW, Chen JX, Xia PF, Pan A. Association of consumption of sugar-sweetened beverages or artificially sweetened beverages with mortality: a systematic review and dose-response meta-analysis of prospective cohort studies. Adv Nutr 2021;12:374- 


\section{DOI PubMed PMC}

70. Assy N, Nasser G, Kamayse I, et al. Soft drink consumption linked with fatty liver in the absence of traditional risk factors. Can $J$ Gastroenterol 2008;22:811-6. DOI PubMed PMC

71. Abid A, Taha O, Nseir W, Farah R, Grosovski M, Assy N. Soft drink consumption is associated with fatty liver disease independent of metabolic syndrome. J Hepatol 2009;51:918-24. DOI PubMed

72. Meng G, Zhang B, Yu F, et al. Soft drinks consumption is associated with nonalcoholic fatty liver disease independent of metabolic syndrome in Chinese population. Eur J Nutr 2018;57:2113-21. DOI PubMed

73. Stepien M, Duarte-Salles T, Fedirko V, et al. Consumption of soft drinks and juices and risk of liver and biliary tract cancers in a European cohort. Eur J Nutr 2016;55:7-20. DOI PubMed PMC

74. Li Y, Guo L, He K, Huang C, Tang S. Consumption of sugar-sweetened beverages and fruit juice and human cancer: a systematic review and dose-response meta-analysis of observational studies. J Cancer 2021;12:3077-88. DOI PubMed PMC

75. Ruanpeng D, Thongprayoon C, Cheungpasitporn W, Harindhanavudhi T. Sugar and artificially sweetened beverages linked to obesity: a systematic review and meta-analysis. QJM 2017;110:513-20. DOI PubMed

76. Drouin-Chartier JP, Zheng Y, Li Y, et al. Changes in consumption of sugary beverages and artificially sweetened beverages and subsequent risk of type 2 diabetes: results from three large prospective U.S. cohorts of women and men. Diabetes Care 2019;42:2181-9. DOI PubMed PMC

77. Hirahatake KM, Jacobs DR, Shikany JM, et al. Cumulative intake of artificially sweetened and sugar-sweetened beverages and risk of incident type 2 diabetes in young adults: the Coronary Artery Risk Development In Young Adults (CARDIA) Study. Am J Clin Nutr 2019;110:733-41. DOI PubMed PMC

78. Muraki I, Imamura F, Manson JE, et al. Fruit consumption and risk of type 2 diabetes: results from three prospective longitudinal cohort studies. BMJ 2013;347:f5001. DOI PubMed PMC

79. Jenkins DJ, Srichaikul K, Kendall CW, et al. The relation of low glycaemic index fruit consumption to glycaemic control and risk factors for coronary heart disease in type 2 diabetes. Diabetologia 2011;54:271-9. DOI PubMed PMC

80. Vaisman N, Niv E, Izkhakov Y. Catalytic amounts of fructose may improve glucose tolerance in subjects with uncontrolled noninsulin-dependent diabetes. Clin Nutr 2006;25:617-21. DOI PubMed

81. Moore MC, Davis SN, Mann SL, Cherrington AD. Acute fructose administration improves oral glucose tolerance in adults with type 2 diabetes. Diabetes Care 2001;24:1882-7. DOI PubMed

82. Pepino MY. Metabolic effects of non-nutritive sweeteners. Physiol Behav 2015;152:450-5. DOI PubMed PMC

83. Suez J, Korem T, Zeevi D, et al. Artificial sweeteners induce glucose intolerance by altering the gut microbiota. Nature 2014;514:181-6. DOI PubMed

84. Ma J, Fox CS, Jacques PF, et al. Sugar-sweetened beverage, diet soda, and fatty liver disease in the Framingham Heart Study cohorts. J Hepatol 2015;63:462-9. DOI PubMed PMC

85. Malik VS, Li Y, Pan A, et al. Long-term consumption of sugar-sweetened and artificially sweetened beverages and risk of mortality in US adults. Circulation 2019;139:2113-25. DOI PubMed PMC

86. Anderson JJ, Gray SR, Welsh P, et al. The associations of sugar-sweetened, artificially sweetened and naturally sweet juices with allcause mortality in 198,285 UK Biobank participants: a prospective cohort study. BMC Med 2020;18:97. DOI PubMed PMC

87. Ahmadi S, Mainali R, Nagpal R, et al. Dietary polysaccharides in the amelioration of gut microbiome dysbiosis and metabolic diseases. Obes Control Ther 2017;4:10.15226/2374-8354/4/2/00140. DOI PubMed PMC

88. Esposito K, Marfella R, Ciotola M, et al. Effect of a mediterranean-style diet on endothelial dysfunction and markers of vascular inflammation in the metabolic syndrome: a randomized trial. JAMA 2004;292:1440-6. DOI PubMed

89. Lindström J, Peltonen M, Eriksson JG, et al. High-fibre, low-fat diet predicts long-term weight loss and decreased type 2 diabetes risk: the Finnish diabetes prevention study. Diabetologia 2006;49:912-20. DOI PubMed

90. Pal S, Khossousi A, Binns C, Dhaliwal S, Ellis V. The effect of a fibre supplement compared to a healthy diet on body composition, lipids, glucose, insulin and other metabolic syndrome risk factors in overweight and obese individuals. Br J Nutr 2011;105:90-100. DOI PubMed

91. Ma Y, Olendzki BC, Wang J, et al. Single-component versus multicomponent dietary goals for the metabolic syndrome: a randomized trial. Ann Intern Med 2015;162:248-57. DOI PubMed PMC

92. Tajima R, Kimura T, Enomoto A, et al. No association between fruits or vegetables and non-alcoholic fatty liver disease in middleaged men and women. Nutrition 2019;61:119-24. DOI PubMed

93. Bahrami A, Teymoori F, Eslamparast T, et al. Legume intake and risk of nonalcoholic fatty liver disease. Indian J Gastroenterol 2019;38:55-60. DOI PubMed

94. Krawczyk M, Maciejewska D, Ryterska K, et al. Gut permeability might be improved by dietary fiber in individuals with nonalcoholic fatty liver disease (NAFLD) undergoing weight reduction. Nutrients 2018;10:1793. DOI PubMed PMC

95. Errazuriz I, Dube S, Slama M, et al. Randomized controlled trial of a MUFA or fiber-rich diet on hepatic fat in prediabetes. $J$ Clin Endocrinol Metab 2017;102:1765-74. DOI PubMed PMC

96. Yang Y, Zhang D, Feng N, et al. Increased intake of vegetables, but not fruit, reduces risk for hepatocellular carcinoma: a metaanalysis. Gastroenterology 2014;147:1031-42. DOI PubMed

97. Perdomo CM, Frühbeck G, Escalada J. Impact of nutritional changes on nonalcoholic fatty liver disease. Nutrients 2019;11:677. DOI PubMed PMC

98. Li B, Leung JCK, Chan LYY, Yiu WH, Tang SCW. A global perspective on the crosstalk between saturated fatty acids and Toll-like receptor 4 in the etiology of inflammation and insulin resistance. Prog Lipid Res 2020;77:101020. DOI PubMed 
99. Machado MV, Ravasco P, Jesus L, et al. Blood oxidative stress markers in non-alcoholic steatohepatitis and how it correlates with diet. Scand J Gastroenterol 2008;43:95-102. DOI PubMed

100. Mei S, Ni HM, Manley S, et al. Differential roles of unsaturated and saturated fatty acids on autophagy and apoptosis in hepatocytes. $J$ Pharmacol Exp Ther 2011;339:487-98. DOI PubMed PMC

101. Alnahdi A, John A, Raza H. Augmentation of glucotoxicity, oxidative stress, apoptosis and mitochondrial dysfunction in HepG2 cells by palmitic acid. Nutrients 2019;11:1979. DOI PubMed PMC

102. Machado MV, Cortez-Pinto H. Diet, microbiota, obesity, and NAFLD: a dangerous quartet. Int J Mol Sci 2016;17:481. DOI PubMed PMC

103. Coelho OGL, Cândido FG, Alfenas RCG. Dietary fat and gut microbiota: mechanisms involved in obesity control. Crit Rev Food Sci Nutr 2019;59:3045-53. DOI PubMed

104. Guasch-Ferré M, Babio N, Martínez-González MA, et al; PREDIMED Study Investigators. Dietary fat intake and risk of cardiovascular disease and all-cause mortality in a population at high risk of cardiovascular disease. Am J Clin Nutr 2015;102:156373. DOI PubMed

105. Mozaffarian D, Micha R, Wallace S. Effects on coronary heart disease of increasing polyunsaturated fat in place of saturated fat: a systematic review and meta-analysis of randomized controlled trials. PLoS Med 2010;7:e1000252. DOI PubMed PMC

106. Guveli H, Kenger EB, Ozlu T, Kaya E, Yilmaz Y. Macro- and micronutrients in metabolic (dysfunction) associated fatty liver disease: association between advanced fibrosis and high dietary intake of cholesterol/saturated fatty acids. Eur $J$ Gastroenterol Hepatol 2021. DOI PubMed

107. Zhao L, Deng C, Lin Z, Giovannucci E, Zhang X. Dietary fats, serum cholesterol and liver cancer risk: a systematic review and metaanalysis of prospective studies. Cancers (Basel) 2021;13:1580. DOI PubMed PMC

108. Bjermo H, Iggman D, Kullberg J, et al. Effects of n-6 PUFAs compared with SFAs on liver fat, lipoproteins, and inflammation in abdominal obesity: a randomized controlled trial. Am J Clin Nutr 2012;95:1003-12. DOI PubMed

109. Rosqvist F, Iggman D, Kullberg J, et al. Overfeeding polyunsaturated and saturated fat causes distinct effects on liver and visceral fat accumulation in humans. Diabetes 2014;63:2356-68. DOI PubMed

110. Luukkonen PK, Sädevirta S, Zhou Y, et al. Saturated fat is more metabolically harmful for the human liver than unsaturated fat or simple sugars. Diabetes Care 2018;41:1732-9. DOI PubMed PMC

111. Rosqvist F, Kullberg J, Ståhlman M, et al. Overeating saturated fat promotes fatty liver and ceramides compared with polyunsaturated fat: a randomized trial. J Clin Endocrinol Metab 2019;104:6207-19. DOI PubMed PMC

112. Toshimitsu K, Matsuura B, Ohkubo I, et al. Dietary habits and nutrient intake in non-alcoholic steatohepatitis. Nutrition 2007;23:4652. DOI PubMed

113. Allard JP, Aghdassi E, Mohammed S, et al. Nutritional assessment and hepatic fatty acid composition in non-alcoholic fatty liver disease (NAFLD): a cross-sectional study. J Hepatol 2008;48:300-7. DOI PubMed

114. Yang J, Fernández-Galilea M, Martínez-Fernández L, et al. Oxidative stress and non-alcoholic fatty liver disease: effects of omega-3 fatty acid supplementation. Nutrients 2019;11:872. DOI PubMed PMC

115. Simopoulos A. The importance of the ratio of omega-6/omega-3 essential fatty acids. Biomed Pharmacother 2002;56:365-79. DOI PubMed

116. Araya J, Rodrigo R, Videla LA, et al. Increase in long-chain polyunsaturated fatty acid n - 6/n - 3 ratio in relation to hepatic steatosis in patients with non-alcoholic fatty liver disease. Clin Sci (Lond) 2004;106:635-43. DOI PubMed

117. Pettinelli P, Del Pozo T, Araya J, et al. Enhancement in liver SREBP-1c/PPAR-alpha ratio and steatosis in obese patients: correlations with insulin resistance and n-3 long-chain polyunsaturated fatty acid depletion. Biochim Biophys Acta 2009;1792:1080-6. DOI PubMed

118. Sawada N, Inoue M, Iwasaki M, et al; Japan Public Health Center-Based Prospective Study Group. Consumption of n-3 fatty acids and fish reduces risk of hepatocellular carcinoma. Gastroenterology 2012;142:1468-75. DOI PubMed

119. Gao M, Sun K, Guo M, et al. Fish consumption and n-3 polyunsaturated fatty acids, and risk of hepatocellular carcinoma: systematic review and meta-analysis. Cancer Causes Control 2015;26:367-76. DOI PubMed

120. Luo J, Yang Y, Liu J, et al. Systematic review with meta-analysis: meat consumption and the risk of hepatocellular carcinoma. Aliment Pharmacol Ther 2014;39:913-22. DOI PubMed

121. Ma Y, Yang W, Li T, et al. Meat intake and risk of hepatocellular carcinoma in two large US prospective cohorts of women and men. Int J Epidemiol 2019;48:1863-71. DOI PubMed PMC

122. Hartweg J, Perera R, Montori V, Dinneen S, Neil HA, Farmer A. Omega-3 polyunsaturated fatty acids (PUFA) for type 2 diabetes mellitus. Cochrane Database Syst Rev 2008:CD003205. DOI PubMed

123. $\mathrm{Hu}$ Y, Hu FB, Manson JE. Marine omega-3 supplementation and cardiovascular disease: an updated meta-analysis of 13 randomized controlled trials involving 127477 participants. J Am Heart Assoc 2019;8:e013543. DOI PubMed PMC

124. Parker HM, Johnson NA, Burdon CA, Cohn JS, O'Connor HT, George J. Omega-3 supplementation and non-alcoholic fatty liver disease: a systematic review and meta-analysis. J Hepatol 2012;56:944-51. DOI PubMed

125. Sanyal AJ, Abdelmalek MF, Suzuki A, Cummings OW, Chojkier M; EPE-A Study Group. No significant effects of ethyleicosapentanoic acid on histologic features of nonalcoholic steatohepatitis in a phase 2 trial. Gastroenterology 2014;147:377-84.e1. DOI PubMed

126. Lee CH, Fu Y, Yang SJ, Chi CC. Effects of omega-3 polyunsaturated fatty acid supplementation on non-alcoholic fatty liver: a systematic review and meta-analysis. Nutrients 2020;12:2769. DOI PubMed PMC

127. Bozzetto L, Prinster A, Annuzzi G, et al. Liver fat is reduced by an isoenergetic MUFA diet in a controlled randomized study in type 
2 diabetic patients. Diabetes Care 2012;35:1429-35. DOI PubMed PMC

128. Abenavoli L, Milanović M, Milić N, Luzza F, Giuffrè AM. Olive oil antioxidants and non-alcoholic fatty liver disease. Expert Rev Gastroenterol Hepatol 2019;13:739-49. DOI PubMed

129. Buckland G, Mayén AL, Agudo A, et al. Olive oil intake and mortality within the Spanish population (EPIC-Spain). Am J Clin Nutr 2012;96:142-9. DOI PubMed

130. Sofi F, Giangrandi I, Cesari F, et al. Effects of a 1-year dietary intervention with n-3 polyunsaturated fatty acid-enriched olive oil on non-alcoholic fatty liver disease patients: a preliminary study. Int J Food Sci Nutr 2010;61:792-802. DOI PubMed

131. Shidfar F, Bahrololumi SS, Doaei S, Mohammadzadeh A, Gholamalizadeh M, Mohammadimanesh A. The effects of extra virgin olive oil on alanine aminotransferase, aspartate aminotransferase, and ultrasonographic indices of hepatic steatosis in nonalcoholic fatty liver disease patients undergoing low calorie diet. Can J Gastroenterol Hepatol 2018;2018:1053710. DOI PubMed PMC

132. Rezaei S, Akhlaghi M, Sasani MR, Barati Boldaji R. Olive oil lessened fatty liver severity independent of cardiometabolic correction in patients with non-alcoholic fatty liver disease: a randomized clinical trial. Nutrition 2019;57:154-61. DOI PubMed

133. Mazidi M, Katsiki N, Mikhailidis DP, Banach M. Link between plasma trans-fatty acid and fatty liver is moderated by adiposity. Int $J$ Cardiol 2018;272:316-22. DOI PubMed

134. Neuschwander-Tetri BA, Ford DA, Acharya S, et al. Dietary trans-fatty acid induced NASH is normalized following loss of transfatty acids from hepatic lipid pools. Lipids 2012;47:941-50. DOI PubMed PMC

135. Dowman JK, Hopkins LJ, Reynolds GM, et al. Development of hepatocellular carcinoma in a murine model of nonalcoholic steatohepatitis induced by use of a high-fat/fructose diet and sedentary lifestyle. Am J Pathol 2014;184:1550-61. DOI PubMed PMC

136. Schnabel L, Kesse-Guyot E, Allès B, et al. Association between ultraprocessed food consumption and risk of mortality among middle-aged adults in France. JAMA Intern Med 2019;179:490-8. DOI PubMed PMC

137. Lane MM, Davis JA, Beattie S, et al. Ultraprocessed food and chronic noncommunicable diseases: a systematic review and metaanalysis of 43 observational studies. Obes Rev 2021;22:e13146. DOI PubMed

138. Mendonça RD, Lopes AC, Pimenta AM, Gea A, Martinez-Gonzalez MA, Bes-Rastrollo M. Ultra-processed food consumption and the incidence of hypertension in a mediterranean cohort: The Seguimiento Universidad de Navarra Project. Am J Hypertens 2017;30:358-66. DOI PubMed

139. Srour B, Fezeu LK, Kesse-Guyot E, et al. Ultraprocessed food consumption and risk of type 2 diabetes among participants of the NutriNet-Santé prospective cohort. JAMA Intern Med 2020;180:283-91. DOI PubMed PMC

140. Fiolet T, Srour B, Sellem L, et al. Consumption of ultra-processed foods and cancer risk: results from NutriNet-Santé prospective cohort. BMJ 2018;360:k322. DOI PubMed PMC

141. Yasutake K, Nakamuta M, Shima Y, et al. Nutritional investigation of non-obese patients with non-alcoholic fatty liver disease: the significance of dietary cholesterol. Scand J Gastroenterol 2009;44:471-7. DOI PubMed

142. Simoni-Nieves A, Salas-Silva S, Chávez-Rodríguez L, et al. The consumption of cholesterol-enriched diets conditions the development of a subtype of HCC with high aggressiveness and poor prognosis. Cancers (Basel) 2021;13:1721. DOI PubMed PMC

143. Machado MV. Nonalcoholic fatty liver disease in lean subjects: is it all metabolic-associated fatty liver disease? Hepatoma Res 2020;6:84. DOI

144. Ioannou GN. The role of cholesterol in the pathogenesis of NASH. Trends Endocrinol Metab 2016;27:84-95. DOI PubMed

145. Bortolotti M, Kreis R, Debard C, et al. High protein intake reduces intrahepatocellular lipid deposition in humans. Am J Clin Nutr 2009;90:1002-10. DOI PubMed

146. Markova M, Pivovarova O, Hornemann S, et al. Isocaloric diets high in animal or plant protein reduce liver fat and inflammation in individuals with type 2 diabetes. Gastroenterology 2017;152:571-85.e8. DOI PubMed

147. Drummen M, Dorenbos E, Vreugdenhil ACE, et al. Long-term effects of increased protein intake after weight loss on intrahepatic lipid content and implications for insulin sensitivity: a PREVIEW study. Am J Physiol Endocrinol Metab 2018;315:E885-91. DOI PubMed

148. Arciero PJ, Gentile CL, Pressman R, et al. Moderate protein intake improves total and regional body composition and insulin sensitivity in overweight adults. Metabolism 2008;57:757-65. DOI PubMed

149. Wycherley TP, Moran LJ, Clifton PM, Noakes M, Brinkworth GD. Effects of energy-restricted high-protein, low-fat compared with standard-protein, low-fat diets: a meta-analysis of randomized controlled trials. Am J Clin Nutr 2012;96:1281-98. DOI PubMed

150. Haghighat N, Ashtary-Larky D, Bagheri R, et al. The effect of 12 weeks of euenergetic high-protein diet in regulating appetite and body composition of women with normal-weight obesity: a randomised controlled trial. Br J Nutr 2020;124:1044-51. DOI PubMed

151. Peng LN, Yu PC, Lee HF, Lin MH, Chen LK. Protein-enriched diet improved muscle endurance and marginally reduced intramuscular adiposity: results from a randomized controlled trial among middle-aged and older adults. Arch Gerontol Geriatr 2021;96:104436. DOI PubMed

152. Blachier F, Beaumont M, Portune KJ, et al. High-protein diets for weight management: Interactions with the intestinal microbiota and consequences for gut health. A position paper by the my new gut study group. Clin Nutr 2019;38:1012-22. DOI PubMed

153. Ko GJ, Rhee CM, Kalantar-Zadeh K, Joshi S. The effects of high-protein diets on kidney health and longevity. J Am Soc Nephrol 2020;31:1667-79. DOI PubMed PMC

154. Kim E, Coelho D, Blachier F. Review of the association between meat consumption and risk of colorectal cancer. Nutr Res 2013;33:983-94. DOI PubMed

155. Díaz-Rúa R, Keijer J, Palou A, van Schothorst EM, Oliver P. Long-term intake of a high-protein diet increases liver triacylglycerol deposition pathways and hepatic signs of injury in rats. J Nutr Biochem 2017;46:39-48. DOI PubMed 
156. Shang X, Scott D, Hodge AM, et al. Dietary protein intake and risk of type 2 diabetes: results from the Melbourne Collaborative Cohort Study and a meta-analysis of prospective studies. Am J Clin Nutr 2016;104:1352-65. DOI PubMed

157. Shang X, Scott D, Hodge A, et al. Dietary protein from different food sources, incident metabolic syndrome and changes in its components: an 11-year longitudinal study in healthy community-dwelling adults. Clin Nutr 2017;36:1540-8. DOI PubMed

158. Tharrey M, Mariotti F, Mashchak A, Barbillon P, Delattre M, Fraser GE. Patterns of plant and animal protein intake are strongly associated with cardiovascular mortality: the Adventist Health Study-2 cohort. Int J Epidemiol 2018;47:1603-12. DOI PubMed $\mathrm{PMC}$

159. Navas-Carretero S, San-Cristobal R, Livingstone KM, et al. Higher vegetable protein consumption, assessed by an isoenergetic macronutrient exchange model, is associated with a lower presence of overweight and obesity in the web-based Food4me European study. Int J Food Sci Nutr 2019;70:240-53. DOI PubMed

160. Naghshi S, Sadeghi O, Willett WC, Esmaillzadeh A. Dietary intake of total, animal, and plant proteins and risk of all cause, cardiovascular, and cancer mortality: systematic review and dose-response meta-analysis of prospective cohort studies. $B M J$ 2020;370:m2412. DOI PubMed PMC

161. Mariotti F. Animal and plant protein sources and cardiometabolic health. Adv Nutr 2019;10:S351-66. DOI PubMed PMC

162. Sobiecki JG, Appleby PN, Bradbury KE, Key TJ. High compliance with dietary recommendations in a cohort of meat eaters, fish eaters, vegetarians, and vegans: results from the European Prospective Investigation into Cancer and Nutrition-Oxford study. Nutr Res 2016;36:464-77. DOI PubMed PMC

163. Etemadi A, Sinha R, Ward MH, et al. Mortality from different causes associated with meat, heme iron, nitrates, and nitrites in the NIH-AARP Diet and Health Study: population based cohort study. BMJ 2017;357:j1957. DOI PubMed PMC

164. Freedman ND, Cross AJ, McGlynn KA, et al. Association of meat and fat intake with liver disease and hepatocellular carcinoma in the NIH-AARP cohort. J Natl Cancer Inst 2010;102:1354-65. DOI PubMed PMC

165. Shi L, Liu ZW, Li Y, et al. The prevalence of nonalcoholic fatty liver disease and its association with lifestyle/dietary habits among university faculty and staff in Chengdu. Biomed Environ Sci 2012;25:383-91. DOI PubMed

166. Zelber-Sagi S, Ivancovsky-Wajcman D, Fliss Isakov N, et al. High red and processed meat consumption is associated with nonalcoholic fatty liver disease and insulin resistance. J Hepatol 2018;68:1239-46. DOI PubMed

167. Zheng W, Lee SA. Well-done meat intake, heterocyclic amine exposure, and cancer risk. Nutr Cancer 2009;61:437-46. DOI PubMed PMC

168. Uribarri J, Woodruff S, Goodman S, et al. Advanced glycation end products in foods and a practical guide to their reduction in the diet. J Am Diet Assoc 2010;110:911-16.e12. DOI PubMed PMC

169. Ivancovsky-Wajcman D, Zelber-Sagi S, Fliss Isakov N, et al. Serum soluble receptor for AGE (sRAGE) levels are associated with unhealthy lifestyle and nonalcoholic fatty liver disease. Clin Transl Gastroenterol 2019;10:1-10. DOI PubMed PMC

170. Kani AH, Alavian SM, Esmaillzadeh A, Adibi P, Azadbakht L. Effects of a novel therapeutic diet on liver enzymes and coagulating factors in patients with non-alcoholic fatty liver disease: a parallel randomized trial. Nutrition 2014;30:814-21. DOI PubMed

171. Xiong P, Zhu YF. Soy diet for nonalcoholic fatty liver disease: a meta-analysis of randomized controlled trials. Medicine (Baltimore) 2021;100:e25817. DOI PubMed PMC

172. Kou T, Wang Q, Cai J, et al. Effect of soybean protein on blood pressure in postmenopausal women: a meta-analysis of randomized controlled trials. Food Funct 2017;8:2663-71. DOI PubMed

173. Rizzo NS, Jaceldo-Siegl K, Sabate J, Fraser GE. Nutrient profiles of vegetarian and nonvegetarian dietary patterns. J Acad Nutr Diet 2013;113:1610-9. DOI PubMed PMC

174. Dixon JB, Bhathal PS, O'Brien PE. Nonalcoholic fatty liver disease: predictors of nonalcoholic steatohepatitis and liver fibrosis in the severely obese. Gastroenterology 2001;121:91-100. DOI PubMed

175. Kwon HK, Greenson JK, Conjeevaram HS. Effect of lifetime alcohol consumption on the histological severity of non-alcoholic fatty liver disease. Liver Int 2014;34:129-35. DOI PubMed

176. Dunn W, Sanyal AJ, Brunt EM, et al. Modest alcohol consumption is associated with decreased prevalence of steatohepatitis in patients with non-alcoholic fatty liver disease (NAFLD). J Hepatol 2012;57:384-91. DOI PubMed PMC

177. Mitchell T, Jeffrey GP, de Boer B, et al. Type and pattern of alcohol consumption is associated with liver fibrosis in patients with non-alcoholic fatty liver disease. Am J Gastroenterol 2018;113:1484-93. DOI PubMed

178. Yamada K, Mizukoshi E, Seike T, et al. Light alcohol consumption has the potential to suppress hepatocellular injury and liver fibrosis in non-alcoholic fatty liver disease. PLoS One 2018;13:e0191026. DOI PubMed PMC

179. Moriya A, Iwasaki Y, Ohguchi S, et al. Roles of alcohol consumption in fatty liver: a longitudinal study. J Hepatol 2015;62:921-7. DOI PubMed

180. Hagström H, Nasr P, Ekstedt M, et al. Low to moderate lifetime alcohol consumption is associated with less advanced stages of fibrosis in non-alcoholic fatty liver disease. Scand J Gastroenterol 2017;52:159-65. DOI PubMed

181. Hashimoto Y, Hamaguchi M, Kojima T, et al. Modest alcohol consumption reduces the incidence of fatty liver in men: a populationbased large-scale cohort study. J Gastroenterol Hepatol 2015;30:546-52. DOI PubMed

182. Åberg F, Färkkilä M. Drinking and obesity: alcoholic liver disease/nonalcoholic fatty liver disease interactions. Semin Liver Dis 2020;40:154-62. DOI PubMed

183. Long MT, Massaro JM, Hoffmann U, Benjamin EJ, Naimi TS. Alcohol use is associated with hepatic steatosis among persons with presumed nonalcoholic fatty liver disease. Clin Gastroenterol Hepatol 2020;18:1831-1841.e5. DOI PubMed PMC

184. Ekstedt M, Franzén LE, Holmqvist M, et al. Alcohol consumption is associated with progression of hepatic fibrosis in non-alcoholic fatty liver disease. Scand J Gastroenterol 2009;44:366-74. DOI PubMed 
185. Åberg F, Helenius-Hietala J, Puukka P, Jula A. Binge drinking and the risk of liver events: a population-based cohort study. Liver Int 2017;37:1373-81. DOI PubMed

186. Kashiwagi K, Yamaguchi A, Shiba S, et al. Moderate alcohol consumption is not associated with subclinical cardiovascular damage but with hepatic fibrosis in non-alcoholic fatty liver disease. Alcohol 2020;89:1-7. DOI PubMed

187. Blomdahl J, Nasr P, Ekstedt M, Kechagias S. Moderate alcohol consumption is associated with advanced fibrosis in non-alcoholic fatty liver disease and shows a synergistic effect with type 2 diabetes mellitus. Metabolism 2021;115:154439. DOI PubMed

188. Ajmera V, Belt P, Wilson LA, et al; Nonalcoholic Steatohepatitis Clinical Research Network. Among patients with nonalcoholic fatty liver disease, modest alcohol use is associated with less improvement in histologic steatosis and steatohepatitis. Clin Gastroenterol Hepatol 2018;16:1511-20.e5. DOI PubMed PMC

189. Chang Y, Cho YK, Kim Y, et al. Nonheavy drinking and worsening of noninvasive fibrosis markers in nonalcoholic fatty liver disease: a cohort study. Hepatology 2019;69:64-75. DOI PubMed

190. Chang Y, Ryu S, Kim Y, et al. Low levels of alcohol consumption, obesity, and development of fatty liver with and without evidence of advanced fibrosis. Hepatology 2020;71:861-73. DOI PubMed

191. Åberg F, Helenius-Hietala J, Puukka P, Färkkilä M, Jula A. Interaction between alcohol consumption and metabolic syndrome in predicting severe liver disease in the general population. Hepatology 2018;67:2141-9. DOI PubMed

192. Ruhl CE, Everhart JE. Joint effects of body weight and alcohol on elevated serum alanine aminotransferase in the United States population. Clin Gastroenterol Hepatol 2005;3:1260-8. DOI PubMed

193. Alatalo PI, Koivisto HM, Hietala JP, Puukka KS, Bloigu R, Niemelä OJ. Effect of moderate alcohol consumption on liver enzymes increases with increasing body mass index. Am J Clin Nutr 2008;88:1097-103. DOI PubMed

194. Loomba R, Bettencourt R, Barrett-Connor E. Synergistic association between alcohol intake and body mass index with serum alanine and aspartate aminotransferase levels in older adults: the Rancho Bernardo Study. Aliment Pharmacol Ther 2009;30:1137-49. DOI PubMed PMC

195. Hart CL, Morrison DS, Batty GD, Mitchell RJ, Davey Smith G. Effect of body mass index and alcohol consumption on liver disease: analysis of data from two prospective cohort studies. BMJ 2010;340:c1240. DOI PubMed PMC

196. Liu B, Balkwill A, Reeves G, Beral V; Million Women Study Collaborators. Body mass index and risk of liver cirrhosis in middle aged UK women: prospective study. BMJ 2010;340:c912. DOI PubMed PMC

197. Loomba R, Yang HI, Su J, et al. Synergism between obesity and alcohol in increasing the risk of hepatocellular carcinoma: a prospective cohort study. Am J Epidemiol 2013;177:333-42. DOI PubMed PMC

198. Ascha MS, Hanouneh IA, Lopez R, Tamimi TA, Feldstein AF, Zein NN. The incidence and risk factors of hepatocellular carcinoma in patients with nonalcoholic steatohepatitis. Hepatology 2010;51:1972-8. DOI PubMed

199. Hajifathalian K, Torabi Sagvand B, McCullough AJ. Effect of alcohol consumption on survival in nonalcoholic fatty liver disease: a national prospective cohort study. Hepatology 2019;70:511-21. DOI PubMed PMC

200. GBD 2016 Alcohol Collaborators. Alcohol use and burden for 195 countries and territories, 1990-2016: a systematic analysis for the Global Burden of Disease Study 2016. Lancet 2018;392:1015-35. DOI PubMed PMC

201. Wijarnpreecha K, Thongprayoon C, Ungprasert P. Coffee consumption and risk of nonalcoholic fatty liver disease: a systematic review and meta-analysis. Eur J Gastroenterol Hepatol 2017;29:e8-e12. DOI PubMed

202. Hayat U, Siddiqui AA, Okut H, Afroz S, Tasleem S, Haris A. The effect of coffee consumption on the non-alcoholic fatty liver disease and liver fibrosis: A meta-analysis of 11 epidemiological studies. Ann Hepatol 2021;20:100254. DOI PubMed

203. Chen YP, Lu FB, Hu YB, Xu LM, Zheng MH, Hu ED. A systematic review and a dose-response meta-analysis of coffee dose and nonalcoholic fatty liver disease. Clin Nutr 2019;38:2552-7. DOI PubMed

204. Zelber-Sagi S, Salomone F, Webb M, et al. Coffee consumption and nonalcoholic fatty liver onset: a prospective study in the general population. Transl Res 2015;165:428-36. DOI PubMed

205. Sewter R, Heaney S, Patterson A. Coffee consumption and the progression of NAFLD: a systematic review. Nutrients 2021;13:2381. DOI PubMed PMC

206. Crozier TW, Stalmach A, Lean ME, Crozier A. Espresso coffees, caffeine and chlorogenic acid intake: potential health implications. Food Funct 2012;3:30-3. DOI PubMed

207. Anty R, Marjoux S, Iannelli A, et al. Regular coffee but not espresso drinking is protective against fibrosis in a cohort mainly composed of morbidly obese European women with NAFLD undergoing bariatric surgery. J Hepatol 2012;57:1090-6. DOI PubMed

208. Xiao Q, Sinha R, Graubard BI, Freedman ND. Inverse associations of total and decaffeinated coffee with liver enzyme levels in National Health and Nutrition Examination Survey 1999-2010. Hepatology 2014;60:2091-8. DOI PubMed PMC

209. Kennedy OJ, Roderick P, Buchanan R, Fallowfield JA, Hayes PC, Parkes J. Coffee, including caffeinated and decaffeinated coffee, and the risk of hepatocellular carcinoma: a systematic review and dose-response meta-analysis. BMJ Open 2017;7:e13739. DOI PubMed PMC

210. Zelber-Sagi S. Dietary treatment for NAFLD: new clinical and epidemiological evidence and updated recommendations. Semin Liver Dis 2021;41:248-62. DOI PubMed

211. Anania C, Perla FM, Olivero F, Pacifico L, Chiesa C. Mediterranean diet and nonalcoholic fatty liver disease. World J Gastroenterol 2018;24:2083-94. DOI PubMed PMC

212. Eslamparast T, Tandon P, Raman M. Dietary composition independent of weight loss in the management of non-alcoholic fatty liver disease. Nutrients 2017;9:800. DOI PubMed PMC

213. Kontogianni MD, Tileli N, Margariti A, et al. Adherence to the Mediterranean diet is associated with the severity of non-alcoholic fatty liver disease. Clin Nutr 2014;33:678-83. DOI PubMed 
214. Aller R, Izaola O, de la Fuente B, De Luis Román DA. Mediterranean diet is associated with liver histology in patients with non alcoholic fatty liver disease. Nutr Hosp 2015;32:2518-24. DOI PubMed

215. Trovato FM, Martines GF, Brischetto D, Trovato G, Catalano D. Neglected features of lifestyle: their relevance in non-alcoholic fatty liver disease. World J Hepatol 2016;8:1459-65. DOI PubMed PMC

216. Corte C, Mosca A, Vania A, Alterio A, Iasevoli S, Nobili V. Good adherence to the Mediterranean diet reduces the risk for NASH and diabetes in pediatric patients with obesity: the results of an Italian Study. Nutrition 2017;39-40:8-14. DOI PubMed

217. Turati F, Trichopoulos D, Polesel J, et al. Mediterranean diet and hepatocellular carcinoma. J Hepatol 2014;60:606-11. DOI PubMed

218. Ryan MC, Itsiopoulos C, Thodis T, et al. The Mediterranean diet improves hepatic steatosis and insulin sensitivity in individuals with non-alcoholic fatty liver disease. J Hepatol 2013;59:138-43. DOI PubMed

219. Trovato FM, Catalano D, Martines GF, Pace P, Trovato GM. Mediterranean diet and non-alcoholic fatty liver disease: the need of extended and comprehensive interventions. Clin Nutr 2015;34:86-8. DOI PubMed

220. Cueto-Galán R, Barón FJ, Valdivielso P, et al; los investigadores del Estudio PREDIMED. Changes in fatty liver index after consuming a Mediterranean diet: 6-year follow-up of the PREDIMED-Malaga trial. Med Clin (Barc) 2017;148:435-43. DOI PubMed

221. Abenavoli L, Greco M, Milic N, et al. Effect of mediterranean diet and antioxidant formulation in non-alcoholic fatty liver disease: a randomized study. Nutrients 2017;9:870. DOI PubMed PMC

222. Katsagoni CN, Papatheodoridis GV, Ioannidou P, et al. Improvements in clinical characteristics of patients with non-alcoholic fatty liver disease, after an intervention based on the Mediterranean lifestyle: a randomised controlled clinical trial. Br J Nutr 2018;120:164-75. DOI PubMed

223. Kaliora AC, Gioxari A, Kalafati IP, Diolintzi A, Kokkinos A, Dedoussis GV. The effectiveness of mediterranean diet in nonalcoholic fatty liver disease clinical course: an intervention study. J Med Food 2019;22:729-40. DOI PubMed

224. Moosavian SP, Arab A, Paknahad Z. The effect of a Mediterranean diet on metabolic parameters in patients with non-alcoholic fatty liver disease: a systematic review of randomized controlled trials. Clin Nutr ESPEN 2020;35:40-6. DOI PubMed

225. Asbaghi O, Choghakhori R, Ashtary-Larky D, Abbasnezhad A. Effects of the Mediterranean diet on cardiovascular risk factors in non-alcoholic fatty liver disease patients: a systematic review and meta-analysis. Clin Nutr ESPEN 2020;37:148-56. DOI PubMed

226. Akhlaghi M, Ghasemi-Nasab M, Riasatian M. Mediterranean diet for patients with non-alcoholic fatty liver disease, a systematic review and meta-analysis of observational and clinical investigations. J Diabetes Metab Disord 2020;19:575-84. DOI PubMed PMC

227. Kawaguchi T, Charlton M, Kawaguchi A, et al. Effects of Mediterranean diet in patients with nonalcoholic fatty liver disease: a systematic review, meta-analysis, and meta-regression analysis of randomized controlled trials. Semin Liver Dis 2021;41:225-34. DOI PubMed

228. Rees K, Takeda A, Martin N, et al. Mediterranean-style diet for the primary and secondary prevention of cardiovascular disease: a Cochrane review. Glob Heart 2020;15:56. DOI PubMed PMC

229. Berná G, Romero-Gomez M. The role of nutrition in non-alcoholic fatty liver disease: pathophysiology and management. Liver Int 2020;40 Suppl 1:102-8. DOI PubMed

230. Hekmatdoost A, Shamsipour A, Meibodi M, Gheibizadeh N, Eslamparast T, Poustchi H. Adherence to the dietary approaches to stop hypertension (DASH) and risk of nonalcoholic fatty liver disease. Int J Food Sci Nutr 2016;67:1024-9. DOI PubMed

231. Xiao ML, Lin JS, Li YH, et al. Adherence to the dietary approaches to stop hypertension (DASH) diet is associated with lower presence of non-alcoholic fatty liver disease in middle-aged and elderly adults. Public Health Nutr 2020;23:674-82. DOI PubMed

232. Zade M, Telkabadi MH, Bahmani F, Salehi B, Farshbaf S, Asemi Z. The effects of DASH diet on weight loss and metabolic status in adults with non-alcoholic fatty liver disease: a randomized clinical trial. Liver Int 2016;36:563-71. DOI PubMed

233. Kang J, Ratamess NA, Faigenbaum AD, et al. Effect of time-restricted feeding on anthropometric, metabolic, and fitness parameters: a systematic review. J Am Coll Nutr 2021:1-16. DOI PubMed

234. Yin C, Li Z, Xiang Y, et al. Effect of intermittent fasting on non-alcoholic fatty liver disease: systematic review and meta-analysis. Front Nutr 2021;8:709683. DOI PubMed PMC

235. Holmer M, Lindqvist C, Petersson S, et al. Treatment of NAFLD with intermittent calorie restriction or low-carb high-fat diet - a randomised controlled trial. JHEP Rep 2021;3:100256. DOI PubMed PMC

236. Younossi ZM, Corey KE, Lim JK. AGA clinical practice update on lifestyle modification using diet and exercise to achieve weight loss in the management of nonalcoholic fatty liver disease: expert review. Gastroenterology 2021;160:912-8. DOI PubMed

237. Chalasani N, Younossi Z, Lavine JE, et al. The diagnosis and management of nonalcoholic fatty liver disease: practice guidance from the American Association for the Study of Liver Diseases. Hepatology 2018;67:328-57. DOI PubMed

238. European Association for the Study of the Liver (EASL), European Association for the Study of Diabetes (EASD), European Association for the Study of Diabetes (EASD). EASL-EASD-EASO Clinical Practice Guidelines for the management of nonalcoholic fatty liver disease. Diabetologia 2016;59:1121-40. DOI

239. Glen J, Floros L, Day C, Pryke R; Guideline Development Group. Non-alcoholic fatty liver disease (NAFLD): summary of NICE guidance. BMJ 2016;354:i4428. DOI PubMed

240. LaBrecque DR, Abbas Z, Anania F, et al; Review Team, World Gastroenterology Organisation. World Gastroenterology Organisation global guidelines: nonalcoholic fatty liver disease and nonalcoholic steatohepatitis. J Clin Gastroenterol 2014;48:46773. DOI PubMed

241. Zelber-Sagi S, Bord S, Dror-Lavi G, et al. Role of illness perception and self-efficacy in lifestyle modification among non-alcoholic 
fatty liver disease patients. World J Gastroenterol 2017;23:1881-90. DOI PubMed PMC

242. Machado MV. Aerobic exercise in the management of metabolic dysfunction associated fatty liver disease. Diabetes Metab Syndr Obes 2021;14:3627-45. DOI PubMed PMC

243. De Chiara F, Ureta Checcllo C, Ramón Azcón J. High protein diet and metabolic plasticity in non-alcoholic fatty liver disease: myths and truths. Nutrients 2019;11:2985. DOI PubMed PMC

244. 2015-2020 Dietary Guidelines For Americans. 2020; 8th ed. Available from: https://health.gov/sites/default/files/2019-09/20152020_Dietary_Guidelines.pdf. [Last accessed on 25 Oct 2021]. 